\title{
SATISFAÇÃO PROFISSIONAL DOS BACHARÉIS EM DIREITO NO PROCESSO DE ESTRUTURAÇÃO DAS CARREIRAS JURÍDICAS ${ }^{1} / /$ Ronit
}

Dinovitzer ${ }^{2}$ e Bryant G. Garth ${ }^{3}$

\begin{abstract}
Resumo
Esse artigo propõe uma nova abordagem para o estudo de satisfação profissional nas carreiras jurídicas. A partir de um quadro analítico Bourdiesiano de compreensão da relação entre classe social e inclinações, sustentamos que satisfação profissional depende em parte das origens sociais e das credenciais relacionadas à essas origens, cujas hierarquias sociais ajudam a definir as expectativas e possibilidades que produzem as carreiras profissionais. Através dessas lentes, satisfação profissional é compreendida como um mecanismo por meio do qual as hierarquias sociais e profissionais são produzidas e reproduzidas. Baseado no primeiro conjunto de dados sobre carreiras jurídicas (incluindo um survey e entrevistas em profundidade), notamos que a origem social dos bacharéis em direito, tal como foi refletida no ranking das suas faculdades de direito, diminui a satisfação na carreira e aumenta a probabilidade de busca de empregos para os bacharéis em direito melhor sucedidos. Quando combinado com os dados das entrevistas, percebemos que classe social é um componente importante de um sistema de estratificação que tende a levar os indivíduos para posições hierarquicamente organizadas.
\end{abstract}

\footnotetext{
1 Texto publicado originalmente na Law \& Society Review, Volume 41, número 1 (2007). Os autores estão listados alfabeticamente. Essa pesquisa foi financiada pela American Bar Foundation, National Science Foundation (Grant No. SES0115521), Access Group, Law School Admission Council, National Association for Law Placement, National Conference of Bar Examiners, e Open Society Institute. As percepções e conclusões apresentadas são dos autores e não necessariamente refletem a visão dos indivíduos ou das organizações associadas com a pesquisa After the JD. Por favor, enviem as correspondências relacionadas para Ronit Dinovitzer, do Departamento de Sociologia da Universidade de Toronto, 725, localizada na Spadina Ave., Toronto, Ontario, M5S 2J4, Canada. Ou para o e-mail: ronit.dinovitzer@utoronto.ca. A versão em português foi traduzida por Izabel Saenger Nuñez e Paloma Monteiro. Ambas Doutorandas em Antropologia no PPGA/UFF.

2 Universidade de Toronto, Osgoode Hall Law School e American Bar Foundation.

3 Escola de Direito da Universidade de Southwestern e American Bar Foundation.
} 


\title{
LAWYER SATISFACTION IN THE PROCESS OF STRUCTURING
}

LEGAL CAREERS // Ronit Dinovitzer and Bryant G. Garth

\begin{abstract}
This article proposes a new approach to the study of job satisfaction in the legal profession. Drawing on a Bourdieusian understanding of the relationship between social class and dispositions, we argue that job satisfaction depends in part on social origins and the credentials related to these origins, with social hierarchies helping to define the expectations and possibilities that produce professional careers. Through this lens, job satisfaction is understood as a mechanism through which social and professional hierarchies are produced and reproduced. Relying on the first national data set on lawyer careers (including both survey data and in-depth interviews), we find that lawyers' social background, as reflected in the ranking of their law school, decreases career satisfaction and increases the odds of a job search for the most successful new lawyers. When combined with the interview data, we find that social class is an important component of a stratification system that tends to lead individuals into hierarchically arranged positions.
\end{abstract}




\section{Introdução}

A literatura disponível sobre satisfação profissional dos bacharéis em direito tende a tomar uma de duas formas. Uma delas vem daqueles procurando tornar a profissão, e especialmente as grandes bancas advocatícias, mais abertas e humanas. Essa literatura pinta uma imagem sombria (Rhode 2000) da profissão em crise (Kronman 1993) baseando-se em dados sobre depressão e uso de álcool entre os profissionais, ou a partir de medidas mais gerais de insatisfação com a carreira (e.g. Glendon 1994; Schiltz 1999; Rhode 2000).

Muitos desses trabalhos destacam a falta de oportunidades iguais dentro das carreiras, focando na insatisfação relativa das mulheres e bacharéis negros (e.g. Rhode 2000). Esses achados são frequentemente apanhados, reutilizados e transmitidos pela imprensa popular, cujas manchetes frequentemente reproduzem dados de pesquisas sobre escritórios de advocacia ou pesquisas com baixas quantidades de respondentes, que tendem a sobrerepresentar a população mais insatisfeita de bacharéis em direito (Dolan 1995, A1; Muir 1995, 16). O quadro geral é o de uma profissão que não faz muito para lidar com o descontentamento observado.

Em contraste, uma segunda literatura, tipicamente derivada de uma ciência social mais sistemática, tende a minimizar o problema da insatisfação profissional entre os bacharéis em direito. As pesquisas empíricas frequentemente apontam que os formandos são relativamente satisfeitos através de uma série de medidas (Hirsch 1985; Taber et al. 1988; Tucker, Albright \& Busk 1989; Gellis 1991; Heinz et al. 2005), e que esses dados são bastante estáveis entre gênero (Chambers 1989; Hagan \& Kay 1995) e raça (Dau-Schmidt \& Mukhopadhaya 1999). Esses relatórios de satisfação relativa, no entanto, precisam ser contextualizados pelos resultados mais gerais de que a maior parte das pessoas, dentre a maioria das ocupações, tende a apontar que estão satisfeitos com o que fazem. (Firebaugh \& Harley 1995).

Sob as duas vertentes de trabalho a respeito da satisfação profissional está implícita a suposição de que as diferenças na satisfação são sintomas de discriminação e desigualdade dentro da profissão. Essa hipótese não surpreende. Décadas de trabalho sobre as profissões jurídicas tem confirmado que existem hierarquias na profissão que todo o bacharel em direito conhece. $O$ acesso às posições mais prestigiosas não tem sido alcançado por mulheres e minorias na proporção das suas representações dentre os profissionais (veja Carson 2004; NALP 2004). Ao mesmo tempo, entretanto, essa desigualdade não é consistentemente refletida nas medidas de satisfação no trabalho e é essa disjunção entre as expressões de satisfação profissional dentro das estruturas de desigualdade que pede uma nova abordagem para compreender a satisfação entre os bacharéis em direito. Por esse motivo nós pretendemos, neste artigo, levar a literatura sobre satisfação no trabalho nas profissões jurídicas para longe dos modelos que avaliam o interesse interno no trabalho dos juristas ou explicam as diferenças na satisfação baseadas somente nos obstáculos ou recompensas que os bacharéis em direito disfrutam dentro da profissão.

Ao invés de assumir a satisfação na profissão como um problema persistente, ou como uma não problemática, ou simplesmente uma questão de discriminação, esse artigo sustenta que a satisfação no trabalho deve ser entendida tanto como manifestação, quanto um fator em um sistema de estratificação que tende a levar os indivíduos para posições hierarquicamente arranjadas. Nós sustentamos que a satisfação no trabalho depende, em parte, das origens sociais e das credenciais relacionadas a essas origens, com as hierarquias sociais que ajudam a definir as expectativas e possibilidades que produzem as carreiras profissionais.

Como Bourdieu (1998) demonstra em The State Nobility, na França, por exemplo, as posições de classe não apenas explicam quais escolas os alunos irão frequentar, mas como essas origens sociais também afetam o quão bem os alunos se adequarão aos projetos pedagógicos de cada uma dessas escolas. De fato, o trabalho de Bourdieu tem demonstrado claramente as formas por meio das quais as disposições individuais, em uma variedade de campos, dos gostos para filmes, comida, música ou arte (Bourdieu 1987, 1993), até as aspirações profissionais (Bourdieu 1998), refletem e legitimam a diferenciação social. Uma abordagem Bourdiesiana enfatiza, desse modo, que a estratificação social não é meramente produzida externamente, mas que os indivíduos, ao 
viverem suas vidas, por meio de seus habitus, isto é, do conjunto de práticas e disposições adquiridas por meio da repetição, internalizam o que podem razoavelmente expectar e, mais importante, o que não podem almejar (Calhoun 2002). E, nesse sentido, é comum que suas escolhas e expectativas reproduzam os padrões de estratificação. É importante que lembremos que as disposições que os inclinam para essas conveniências são, elas mesmas, os efeitos encarnados da dominação (Bourdieu 1998:4).

Essa conexão entre origens sociais, estruturas hierárquicas e disposições é ratificada pela pesquisa empírica produzida no campo da sociologia das profissões, cujos estudos revelam que os valores que os indivíduos projetam sobre seus trabalhos são, eles próprios, moldados pelas origens sociais, mais que inculcados por configurações de trabalho específicas (McClelland 1990; Jacobs et al. 1991; Johnson 2001, 2002; Halaby 2003).

Similarmente, as expressões de satisfação com o trabalho estão intimamente ligadas às aspirações e expectativas de carreira. Como Seron (1996) demonstrou em sua pesquisa sobre os advogados que atuam individualmente e sobre pequenos escritórios, muitos desses profissionais vinham de origens sociais menos favorecidas, e vieram para a profissão com o desejo de que o trabalho desse a eles independência e autonomia. Por isso, não desejavam posições em grandes bancas (1996:12).

Levando tudo isso em conta, esse trabalho nos instiga a indagar se as baixas expectativas na carreira podem manter muitos bacharéis satisfeitos, particularmente para quem o fato de entrar na profissão já é propriamente o bilhete para ascender a um status profissional burguês, apesar das posições que lhes oferecem apresentarem pouca possibilidade de mobilidade, tanto para ingressarem na elite jurídica, quanto para se moverem para outras carreiras.

Outros, que naturalmente esperam ter uma posição entre a elite, podem resmungar sobre o trabalho deles, por que este não comporta a imagem que têm sobre onde pertencem, ou por que já saberem que se trata de um momento, até enfim chegarem a um cargo mais alto, talvez no mundo dos negócios ou nas funções dentro do estado. E ainda outros, localizados entre esses dois polos, podem expressar insatisfação em razão de oportunidades relativamente menores junto à elite, por que esperam algo melhor e, mais ainda, por que sentem que não são bem-vindos em certas posições. Esses podem traduzir suas insatisfações por meio da necessidade de deixar seus empregos ou a profissão, com alguns efeitos descendentes nas suas trajetórias profissionais.

Neste artigo, nós concebemos a satisfação profissional como um mecanismo por meio do qual as hierarquias sociais e profissionais são produzidas e reproduzidas. Sustentamos também que a satisfação e insatisfação são parte de um processo que liga algumas pessoas a certas carreiras, fornecendo, estratificando e legitimando as profissões jurídicas e suas várias hierarquias. Satisfação relativa é produzida a partir da química das pessoas, suas experiências, expectativas e suas possibilidades de carreira. 0 processo só pode ser compreendido ao voltarmos o olhar para quem vai para cada faculdade, o que esperam, o que podem ganhar na prática e como percebem o futuro. Satisfação com o trabalho, nesse sentido, é um mecanismo (Stinchcombe 2005:178-180) que conecta os antecedentes sociais com a manutenção das hierarquias profissionais.

O artigo constrói esse argumento ao longo de cinco sessões. Começamos com uma discussão sobre o desenho e a metodologia de um projeto a partir do qual esse trabalho se baseia. A segunda sessão fornece uma revisão de literatura sobre satisfação dos bacharéis em direito. Na terceira sessão começamos a análise desenhando os contornos dos dados sobre satisfação, e na quarta parte combinamos os dados sobre satisfação com variáveis que não estão frequentemente ligadas a ela, como as faculdades de direito frequentadas, as notas e a origem social dos alunos. A quinta parte procura refinar a análise com base em entrevistas em profundidade, para construir modelos de carreiras jurídicas que mostrem as relações entre satisfação no trabalho, origens sociais e acadêmicas e configurações práticas específicas. Esta análise coloca em relevo os processos de construção de satisfação e insatisfação, e também revela alguns dos desafios enfrentados nas profissões jurídicas atualmente, com a conclusão que aponta. 


\subsection{Depois do Estudo DGD}

Este artigo baseia-se nos primeiros dados do estudo Depois da Graduação em Direito (DGD) ${ }^{4}$, uma pesquisa longitudinal nacional de graduados em direito, que conta com uma amostra de um pouco mais de $10 \%$ de todos os indivíduos que se tornaram advogados em 2000 (DINOVITZER et al., 2005). Tal estudo é baseado em uma amostra representativa da população nacional de advogados aprovados no exame da American Bar Association $^{5}$ em 2000, e foi projetado usando um processo de amostragem em duas etapas.

No primeiro estágio, o país foi dividido em 18 camadas, levando em conta a região e volume dessa nova população de advogados. Dentro de cada uma dessas camadas foi escolhida uma unidade primária de amostra (UPA) a partir da área urbana, da porção de um Estado, fora de grandes áreas metropolitanas ou do Estado inteiro. As UPAs incluíam todos os quatro "principais" mercados, que seriam aqueles com mais de 2.000 advogados recém formados (Chicago, Los Angeles, Nova lorque e Washington, capital); cinco dos nove "maiores" mercados, isto é, aqueles que tem entre 750 e 2.000 novos advogados (Boston, Atlanta, Houston, Mineápolis e São Francisco); e nove dos restantes, ou seja, os mercados menores (Conecticute, restante da Nova Jérsei, restante da Flórida, Tennessee, Oklahoma, Indiana, St. Louis, no Missouri, Utah e Óregon).

No segundo estágio, indivíduos foram selecionados em amostragem, em cada uma das UPAs, em taxas que, combinadas, deveriam generalizar a população nacional. Além disto, o estudo incluiu uma sobreamostra de 1.465 recém advogados de grupos considerados minoritários (Negros, Hispânicos e

4 Nota das Tradutoras: No original, After the JD - AJD. Ressaltamos que, nos Estados Unidos, o diploma de (J.D. or JD), também conhecido como grau de Doctor of Jurisprudence (J.D., JD, D.Jur. or DJur), é um diploma de graduação para atuar profissionalmente no campo do direito.

5 N.T. Nos EUA, para que um indivíduo possa atuar como advogado, é preciso que, após três anos cursando uma faculdade de direito (law school), ele seja aprovado nas três provas do exame conhecido como "bar". Dentre as muitas diferenças com relação ao exame da $\mathrm{OAB}$, no Brasil, as provas da American Bar Association são elaboradas pelos Estados, sob o controle do Judiciário.
Asiático-americanos) ${ }^{6}$. A amostra final incluiu 9.192 advogados nas 18 UPAs.

A coleta de dados se deu através de um questionário enviado por correio, que incluía seções sobre o histórico pessoal e processo de procura de emprego do participante; a natureza do seu atual trabalho, incluindo seu teor, descrição das atividades, ambiente de trabaIho e a satisfação do entrevistado com ele; o histórico da sua faculdade de direito; e uma variedade de condições e circunstâncias anteriores, assim como outras informações contextuais. Após o envio inicial da pesquisa, em maio de 2002, aqueles que não responderam foram contatados por correio e telefone (tendo a pesquisa por telefone utilizado uma versão abreviada do questionário enviado por correio). Aproximadamente 100 entrevistas presenciais aprofundadas foram conduzidas com um subgrupo de entrevistados.

Em torno de $20 \%$ dos indivíduos da amostra não puderam ser localizados, e cerca de $20 \%$ daqueles que o foram, revelaram já serem advogados prestando prova para outra unidade da federação ${ }^{7}$, ao invés de advogados aprovados no exame pela primeira vez. Esses nômades foram incluídos na amostra desde que não tivessem se graduado na faculdade de direito antes de 1998 (consequentemente, 6\% das amostras do DGD iniciaram sua prática legal em 1999, e 1,5\% começaram a exercer em 1998). Da amostra original de membros que foram localizados e cumpriram o critério para inclusão no estudo, $72 \%$ responderam o questionário por correio ou a entrevista por telefone, para um total de 4.538 respostas válidas. A análise neste artigo baseia-se apenas nos dados das amostras nacionais (isto é, a sobreamostra das minorias não está incluída), composta por 3.950 participantes ${ }^{8}$.

$6 \mathrm{~A}$ amostra também incluiu entrevistados que se auto identificaram como Americanos Nativos, embora o número dos que apareceram nesta categoria seja muito pequeno para as análises deste artigo.

7 N.T. Nos Estados Unidos o exame da American Bar é estadual, isto é, cada estado da federação tem o seu próprio exame. Ou seja, os entrevistados estavam fazendo o segundo exame, para atuarem em outro estado.

8 As análises neste artigo baseiam-se em dados não ponderados (uma vez que os pesos finais não foram concluídos no momento da publicação), pelo que os resultados bivariados devem ser interpretados com alguma cautela. Em análises separadas, todas as tabelas bivariadas também foram executadas usando pesos pre- 
Comparações com dados externos indicam que a amostra do DGD é representativa da população geral da qual a amostra fora selecionada. Quando comparada com jovens advogados no censo de 2000, percebemos que a composição racial da amostra é quase idêntica (PUMS 2000, amostra de 5\%, todos advogados e juízes com idade entre 27-32 anos). Na medida em que os cenários podem ser inferidos dos dados do censo, a amostra também se aproxima da distribuição de advogados entre escritórios, governo e empresas (PUMS 2000, amostra de 5\%, todos advogados e juízes; Carson, 2004). Por fim, a distribuição por gênero coincide aproximadamente com os dados publicados pela American Bar Association (American Bar Association, 2005).

\section{Debates sobre Satisfação}

Geralmente, pesquisas acadêmicas sobre profissões jurídicas apontam para altos níveis de satisfação na carreira. Em um dos estudos originais sobre satisfação de advogados no trabalho, Hirsch (1985) apresentou o relatório de uma pesquisa de probabilidade aleatória sobre advogados nos Estados Unidos em que os níveis gerais de satisfação reportados eram altos (68\% dos entrevistados eram muito ou razoavelmente satisfeitos com seu emprego atual).

Resultados similares tem sido encontrados a partir de pesquisas com advogados em todos os Estados Unidos (HIRSCH, 1985; TUCKER, ALBRIGHT \& BUSK, 1989; CHAMBERS, 1989) e em cidades ou regiões específicas (TABER et al., 1988; GELLIS, 1991; ADAMS, 1994; HAGAN \& KAY, 1995; LEMPERT, CHAMBERS \& ADAMS, 2000; HEINZ et al., 2005; BOON, DUFF \& SHINER, 2001). No entanto, a imprensa popular, juntamente com alguns trabalhos acadêmicos, continua a proclamar que o direito é uma carreira insatisfatória (por exemplo, TAZIAN, 2005; PEDONE, 2004; RANALLI, 2003; NATIONAL POST, 2001; EVIATAR, 2000).

Ordenar essa divergência - e, em particular, determinar quem está satisfeito e quem não está - tem sido a principal fonte do debate nesta área. Diante de um

liminares (em arquivo com os autores), com resultados variando apenas marginalmente, e nossos achados essenciais permanecendo muito semelhantes. conjunto de advogados geralmente satisfeitos em suas amostras, o estudo mais recente do Chicago BAR pergunta se "os advogados de Chicago são especiais" (HEINZ et al., 2005, pp.257). A maioria das pesquisas tenta, de modo semelhante, parcelar a satisfação perguntando se certos grupos com a aprovação no BAR - particularmente advogadas mulheres e minorias são aqueles em que se encontra insatisfação na profissão. Porém, novamente os pesquisadores tem se frustrado: na advocacia, mulheres (TABER et al. 1988; CHAMBERS 1989; TUCKER, ALBRIGHT \& BUSK 1989; GELLIS 1991; HAGAN \& KAY 1995; DAU SCHMIDT AND MUKHOPADHAYA 1999; LEMPERT, CHAMBERS \& ADAMS 2000:486, TABLE 33; REICHMAN AND STERLING 2004; HEINZ ET AL. 2005; BOON, DUFF \& SHINER 2001) e minorias (DAU-SCHMIDT \& MUKHOPADHAYA 1999; LEMPERT, CHAMBERS, \& ADAMS 2000; HEINZ et al. 2005) continuam a reportar altos índices gerais de satisfação profissional, ainda que estejam menos satisfeitos com determinados aspectos dos seus trabalhos, ou certos elementos da própria advocacia. Já que mulheres e minorias não gozam, de fato, do mesmo sucesso dos advogados homens e brancos, isto tem levado a um "paradoxo" quanto à satisfação (HULL, 1999) que os pesquisadores continuam a investigar.

Análises de dados sobre os advogados de Chicago, coletados por meio de aproximadamente 800 entrevistas pessoais, tem sido uma importante contribuição para essa literatura (HEINZ et al., 2005). Baseado nesses dados, Hull (1999) levanta dois dos maiores componentes da satisfação no trabalho: satisfação contextual, relacionada ao ambiente de trabalho dos advogados, assim como satisfação com salário e oportunidades de promoção na carreira; e satisfação de conteúdo, que inclui o conteúdo do trabalho, o controle sobre o seu volume e o nível de responsabilidade. Hull acredita que existem diferentes dispositivos para pressupor diferentes tipos de satisfação - por exemplo, dinheiro e o prestígio da área praticada aumentam a satisfação contextual, enquanto trabalhar em uma organização de maior porte diminui a satisfação dita de conteúdo - chamando atenção para a necessidade de incorporar abordagens mais sofisticadas ao estudo da satisfação no trabalho (1999:694; ver também HEINZ et al., 2005).

A pesquisa tem também fornecido pistas adicionais 
sobre a relação entre satisfação profissional e importantes características estruturais da prática jurídica, assim como renda e cenários da prática. A pesquisa sobre os advogados de Chicago descobriu que renda era um indício de alta satisfação, mas que advogados empregados em grandes firmas de advocacia estavam menos satisfeitos do que advogados atuando em outros lugares (HEINZ et al., 2005).

Similarmente, Hagan e Key (1995; 170-2) identificaram que advogados com maiores rendas estão mais satisfeitos com seus empregos, mas entre os atuantes do setor privado, o tamanho da empresa não fazia diferença ${ }^{9}$. Análises dos dados dos alunos da Universidade de Michigan (LEMPERT, CHAMBERS, ADAMS, 2000) sugerem que graduados em direito inseridos no governo, serviços legais/lei de interesse público e educação são significativamente mais satisfeitos do que aqueles atuando no setor privado, apesar das suas rendas serem menores. Outras têm descoberto que, mesmo levando em conta uma ampla gama de fatores, a prática privada em empresas grandes é o tipo menos satisfatório de atuação, ainda que seja o mais lucrativo (DAU-SCHIMIDT, MUKHOPADHAYA, 1999, p. 362).

O consenso nesses estudos é bastante forte - enquanto rendas maiores levam a uma maior satisfação, aqueles que atuam em grandes empresas privadas são relativamente menos satisfeitos com seus trabalhos.

Podemos extrair uma série de conclusões adicionais para melhor contextualizar essa forte relação entre renda, local de atuação e satisfação. Sandefur e Heinz (1999) acreditam que a satisfação com a renda diminui, à medida que a desigualdade de renda aumenta em um campo e que a satisfação com o progresso na carreira tende a diminuir, à medida em que a desigualdade de renda aumenta. Outras características dos contextos de prática profissional que têm sido associados ao aumento da satisfação incluem maior autonomia e possibilidade de tomada

9 Uma vez que a medida das configurações da prática fez a distinção apenas entre aqueles que trabalham em empresas de vinte ou mais advogados, comparados aqueles em ambientes menores, vale a pena notar que os entrevistados com uma prática corporativa grande estavam significativamente menos satisfeitos com seus empregos; esses advogados também podem estar mais propensos a trabalhar em ambientes de empresas maiores. de decisão (HAGAN \& KAY, 1995; HEINZ ET AL. 2005; WALLACE 1995), bem como a colocação em posições de coordenação (MOBLEY et al., 1994).

Enquanto a maioria das pesquisas têm focado nas expressões da satisfação, alguns estudos têm se baseado no volume de trabalho e mudanças de emprego como indicadores de insatisfação - nesse caso, os pesquisadores presumem que aqueles que estão infelizes, mudam de empregos ou pretendem mudar (ver geralmente KALLEBERG, 1977).

Não há dúvida de que a profissão jurídica é caracterizada por altos índices de mobilidade profissional, especialmente entre novos bacharéis ${ }^{10}$, e estudos têm encontrado clara relação entre satisfação e mobilidade profissional. Uma recente pesquisa da ABA (American Bar Association, Young Lawyers Division, 2000) apontou que insatisfação profissional e desejo de um melhor retorno financeiro eram as motivações mais fortes para os entrevistados abandonarem seus empregos atuais (ver também NALP, 2001). A análise de Kay (1997) sobre tais mudanças concluiu que a satisfação no trabalho é uma das chaves para a compreensão das "forças causais e motivações que levam à saída do emprego e a mobilidade horizontal no direito".

Além do mais, em uma análise recente das intenções dos advogados de deixarem seus empregadores e a confiança em escritórios de advocacia, Kay e Hagan (2003) argumentam que a "intenção de deixar a empresa também pode ser vista como uma medida mais concreta de satisfação profissional". Os autores acreditam que a satisfação, tanto com os aspectos intrínsecos (por exemplo, desafio intelectual e prazer no

10 Um relatório recente da NALP (2003) descobriu que 14\% dos associados em início de carreira saíram das empresas no primeiro ano, com um percentual ainda maior (17\%) deixando as grandes (mas não maiores) empresas de 251-500 advogados. Estudos documentaram um aumento dessas taxas de mobilidade nas últimas décadas (Heinz et al, 2005; American Bar Association, Young Lawyers Division, 2000), com um estudo estimando que os advogados que iniciam suas carreiras em pequenas empresas privadas experimentam um movimento a cada 7,7 anos (Heinz et al., 2005) e outro constatando que, com seis anos de graduação na faculdade de direito, quase metade dos advogados na prática privada e quase dois terços daqueles no governo, não estavam mais trabalhando para seu primeiro empregador (American Bar Association, Young Lawyers Division, 2000). 
trabalho jurídico) quanto extrínsecos (por exemplo, remuneração, benefícios no local de trabalho) do trabalho dos advogados aumentam as intenções de permanecer com o escritório. E não surpreende que grande parte da pesquisa sobre mobilidade, como aquela sobre satisfação no trabalho, se concentre em questões de desigualdade, cujos estudos encontram maiores taxas de mobilidade entre as mulheres (KAY 1997; KAY \& HAGAN 2003 ${ }^{11}$; SOMMERLAD \& SANDERSON, 1998) e minorias (HEINZ et al., 2005; WILKINS \& GULATI, 1996).

\section{Contornos básicos da satisfação nos dados do DGD}

Consistente com os achados de estudos anteriores, os níveis de satisfação profissional relatados na pesquisa DGD são altos: quando solicitados a classificar sua satisfação em dezesseis dimensões específicas dos seus empregos, os entrevistados consistentemente se classificavam como mais satisfeitos do que insatisfeitos (ver tabela 1).

Em especial, os bacharéis expressaram maiores níveis de satisfação em suas relações com os colegas de trabalho, seus níveis de responsabilidade, o controle sobre seu trabalho e o desafio intelectual de suas atividades (todos classificando 5.39/7 ou mais), com avaliações um pouco inferiores em seus processos de avaliação de desempenho, diversidade no ambiente de trabalho e suas oportunidades de atuação pro bono (todos avaliando 4.4/7 ou menos). Mais surpreendentemente, a satisfação dos entrevistados com a escolha de carreira é muito alta: $79 \%$ dos entrevistados relataram que são extremamente ou moderadamente satisfeitos com sua decisão de estudar direito.

Em contraste, contudo, quando perguntados por quanto tempo eles planejam ficar no emprego atual, os dados sugerem um padrão diferente, com $44 \%$ dos entrevistados expressando que pretendem procurar

11 As mulheres são mais propensas a expressar intenção de deixar a empresa. Para os homens, a intenção de deixar o cargo é influenciada pela sua satisfação em relação às oportunidades de promoção, remuneração, segurança no emprego e benefícios, mas para as muIheres, os planos para deixar o posto de trabalho são mais fortemente influenciados pela falta de recompensas intrínsecas, incluindo oportunidades limitadas de demonstrar habilidades jurídicas e de alcançar um senso de realização através da prática do direito. um novo emprego dentro de dois anos - e quase $1 / 4$ desses entrevistados expressaram já estarem procurando uma nova posição ou planejar fazer dentro de um ano.

Tabela 1: Médias e Percentagem para Medidas de Satisfação Profissional.

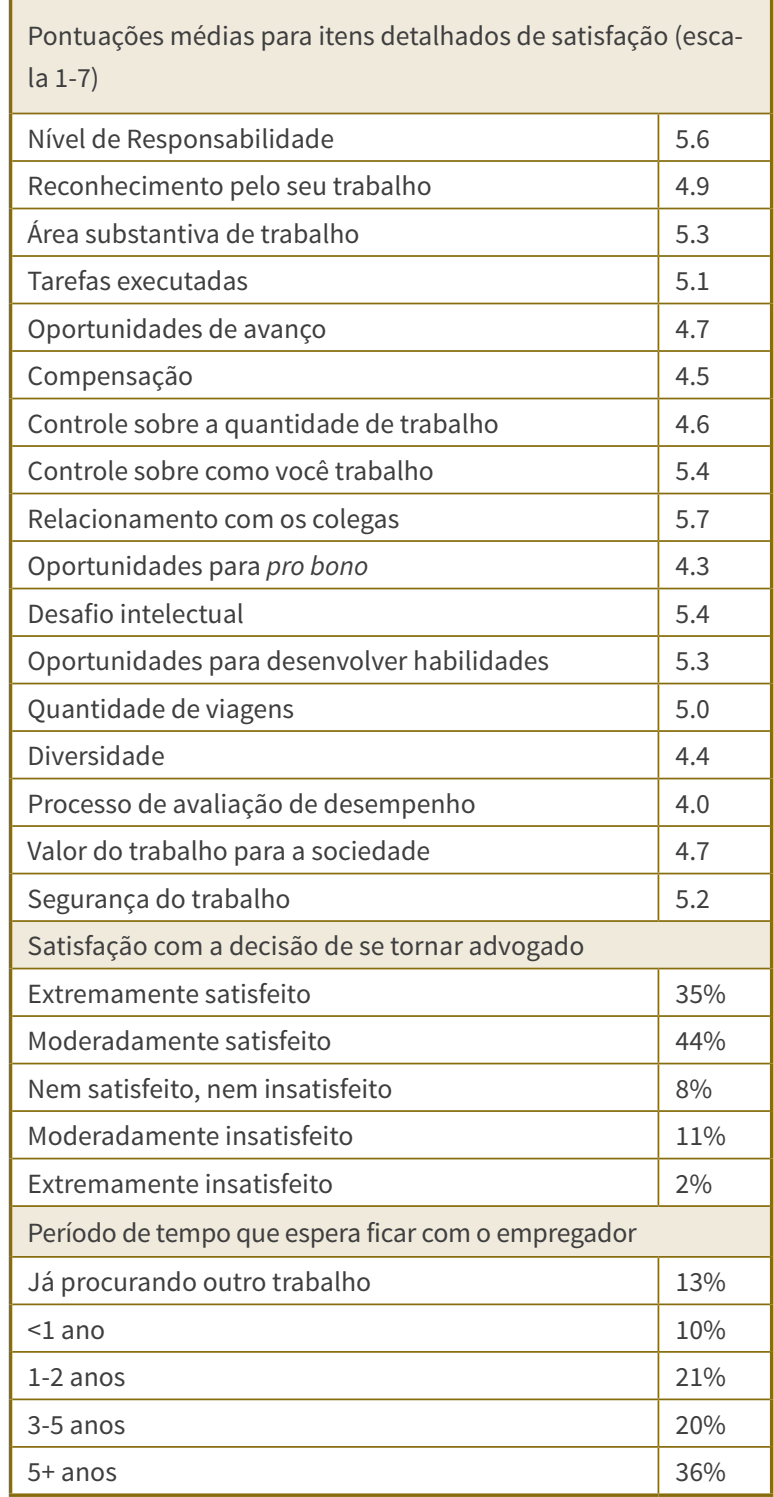

Esses dados apresentam um certo paradoxo: por um lado, encontramos altos níveis de satisfação quanto à decisão de tornarem-se juristas, mas por outro, constatamos níveis razoavelmente altos de desejo de mudança, frequentemente tomado como indicador de baixos níveis de satisfação profissional (KAY \& HAGAN, 2003). Para ficar longe dessa tensão nós desagregamos esses resultados em razão do prestígio da faculdade de direito frequentada pelos entrevistados. 
Como Bourdieu $(1977,1998)$ tem argumentado, escolas são o local-chave onde os alunos assimilam suas expectativas profissionais - desse modo, desempenham um papel crítico na reprodução da estratificação social, pois os estudantes não só adquirem as habilidades que necessitam para a vida profissional, mas também de forma mais acentuada, adaptam-se às disposições necessárias para desempenhar os papéis profissionais que estão destinados a assumir. Isto pode se dar porque as escolas são, elas mesmas, parte na reprodução das origens sociais dos estudantes: o prestígio da escola que os indivíduos frequentam se dá em função de sua classe social, de modo que, ao conceder graus e credenciais, as escolas confirmam e reafirmam o status prévio dos estudantes, dentro da profissão (Bourdieu, 1998). Pesquisas em faculdades de direito - o estudo de Granfield (1992) do Making Elite Lawyers to Stover's (1989), Making It and Breaking It e o trabalho de Mertz (prestes a ser publicado em 2006) sobre Language of Law School - de fato estabelecem que elas são os locais-chave no desenvolvimento das expectativas e aspirações dos estudantes.

Nosso parâmetro para definir a hierarquia das faculdades de direito no conjunto de dados do estudo DGD deriva dos rankings publicados no US News and World Report de 2003; cada escola no conjunto de dados da pesquisa foi atribuída à sua correspondente pontuação no US News e depois foi colocada em um dos seis grupos principais: o top 10 , top 11-20, top 21 40, top 41-100, faculdades no terceiro e quarto níveis. As análises revelam que essas classificações se correlacionam bem com os padrões de origem social dos bacharéis disponíveis nos dados da DGD.

A Tabela 2 indica que os alunos que frequentam as dez melhores escolas elencam pontuações significativamente maiores de prestígio ocupacional dos pais do que aqueles das faculdades de quarto nível. Ou seja, apresentam índices ocupacionais dos pais declinando de forma linear, juntamente com a posição da faculdade de direito. Os dados sobre o nível de escolaridade dos pais mostram um padrão semelhante: mais de $2 / 3$ dos graduados nas dez melhores faculdades tiveram pais que concluíram algum curso superior, em comparação com $1 / 3$ dos graduados do quarto nível.
Tabela 2. Ranking das Faculdades de Direito e Medidas de Estratificação Social

\begin{tabular}{|c|c|c|c|}
\hline & $\begin{array}{l}\text { Pontuação do } \\
\text { Prestígio Ocu- } \\
\text { pacional do Pai } \\
\text { (média) }^{\text {a }}\end{array}$ & $\begin{array}{l}\text { Pai com } \\
\text { Educação } \\
\text { Superior }^{\text {b }}\end{array}$ & $\begin{array}{l}\text { Total } \\
\mathrm{N}\end{array}$ \\
\hline Top 19 & 65.795 (16.525) & $68 \%{ }^{* * *}$ & 174 \\
\hline Top 11-20 & $63.677(17.228)$ & $54 \%{ }^{* \star}$ & 253 \\
\hline Top 21-40 & 63.257 (17.506) & $54 \%{ }^{* \star *}$ & 310 \\
\hline Top 41-100 & $60.272(18.230)$ & $42 \%$ & 686 \\
\hline $3^{\text {a Categoria }}$ & $58.471(17.617)$ & $33 \%{ }^{* \star *}$ & 383 \\
\hline $4^{\mathrm{a}}$ Categoria & $57.231(18.298)$ & $34 \%{ }^{* * *}$ & 318 \\
\hline
\end{tabular}

${ }^{a}$ Resultados de One-Way Anova: $F=13.099, p<0.001$. Os testes post hoc de Bonferroni revelam contrastes significativos ( $p<0.05$ ou maior) entre: os graduados nas top 10 e aqueles das faculdades ranqueadas em $41^{a} \mathrm{e}$ abaixo; graduados nas top 20 e aqueles das faculdades ranqueadas em $41^{a}$ e abaixo; graduados nas top 40 e aqueles de faculdades de $3^{a}$ e $4^{a}$ categorias; graduados nas top 100 e aqueles das faculdades ranqueadas no top 10, top 20 e $4^{a}$ categoria; graduados das faculdades de $3^{a}$ categoria e aqueles das top 10 até top 40; e graduados das faculdades de $4^{a}$ categoria e todos os entrevistados, exceto aqueles graduados nas faculdades de $3^{a}$ categoria.

${ }^{b}$ Testes de significância são para as categorias das faculdades de direito selecionadas comparadas a todas as outras.

Nota: números em parênteses são erros padrão. "p. $<0.05,{ }^{* *}$ p. $<0.01,{ }^{* * *}$ p. $<0.001$ (teste bicaudal).

O ranking das faculdades também se relaciona diretamente com os tipos de trabalho dos graduados em direito, o que indica que as hierarquias sociais que levaram os alunos a determinadas escolas também continuarão 
a ser reproduzidas em suas carreiras profissionais.

Os dados da Tabela 3 indicam que mais da metade dos graduados das faculdades entre as top 10 trabalham nos mega-escritórios ou empresas com mais de 250 advogados, contra apenas $4 \%$ dos graduados das faculdades de quarto nível, que trabalham predominantemente em pequenos escritórios ou sozinhos. Mesmo quando eles trabalham no setor público, os graduados das faculdades de elite têm maior probabilidade de atuar nas posições de maior prestígio, no governo federal, enquanto os graduados de nível inferior são mais propensos a trabalhar para o governo estadual.

Diante desses dados, não surpreende que as medidas de satisfação no trabalho acompanhem a hierarquia das faculdades de direito. Se nosso exame inicial quanto a satisfação profissional resultou paradoxal porque mostrou altos níveis de satisfação ao mesmo tempo em que eram altas as intenções de mobilidade de trabalho, examinar essas mesmas medidas em diálogo com a classificação de faculdades de direito ilumina consideravelmente esta disjunção.
Os dados na Figura 1 indicam que quase $60 \%$ dos graduados nas dez melhores faculdades esperam deixar suas posições dentro de dois anos, enquanto apenas $27 \%$ relatam estar extremamente satisfeitos com sua decisão de se tornarem advogados. Por outro lado, um número substancialmente menor dos graduados nas faculdades de quarta categoria (41\%) pretende deixar seus postos de trabalho dentro de dois anos, enquanto que substancialmente mais desses graduados (43\%) estão extremamente satisfeitos com sua decisão de se tornarem advogados. Esses padrões sugerem que há, de fato, uma convergência, e não uma divergência, entre as expressões de satisfação na carreira e as intenções de mobilidade profissional: a maior parte dos alunos de elite são os menos satisfeitos com a carreira e os mais propensos a deixar seu trabalho, enquanto os graduados de nível inferior expressam níveis maiores de satisfação profissional e de comprometimento com seus empregadores.

Entretanto, pode ser que tal relação entre o nível da faculdade de direito e a satisfação no trabalho tenha mais a ver com os cenários em que esses advogados atuam, ao invés de serem uma consequência direta das

Tabela 3. Ranking das Faculdades de Direito e Contextos de Prática

\begin{tabular}{|c|c|c|c|c|c|c|}
\hline & $\begin{array}{l}\text { Top } \\
1-10\end{array}$ & $\begin{array}{l}\text { Top } \\
11-20\end{array}$ & $\begin{array}{l}\text { Top } \\
21-40\end{array}$ & $\begin{array}{l}\text { Top } \\
41-100\end{array}$ & $\begin{array}{l}3^{a} \text { Categoria } \\
\text { (101 até } 137)\end{array}$ & $\begin{array}{l}4^{a} \text { Categoria } \\
\text { (138 até } 178)\end{array}$ \\
\hline Autônomo & $0.0 \%{ }^{* * *}$ & $2.5 \%$ & $2.5 \%{ }^{*}$ & $4.2 \%$ & $6.4 \%^{* *}$ & $7.8 \%{ }^{* * *}$ \\
\hline Escritório privado $2-20$ & $2.5 \%{ }^{* * *}$ & $12.1 \%{ }^{* * *}$ & $18.75^{*}$ & $27.2 \%{ }^{* *}$ & $33.6 \%{ }^{* * *}$ & $39.2 \%{ }^{* \star *}$ \\
\hline Escritório privado $21-100$ & $6.3 \%$ & $12.1 \%{ }^{* * *}$ & $13.2 \%$ & $14.5 \%$ & $13.9 \%{ }^{* *}$ & $10.2 \%{ }^{* * *}$ \\
\hline Escritório privado $101-251$ & $12.9 \%{ }^{* \star *}$ & $13.3 \%{ }^{* \star *}$ & $10.1 \%{ }^{* \star *}$ & $7.0 \%{ }^{* \star \star}$ & $5.1 \%{ }^{* * *}$ & $3.0 \%{ }^{* * *}$ \\
\hline Escritório privado $251+$ & $53.3 \%{ }^{* \star *}$ & $37.7 \% * *$ & $28.4 \%{ }^{*}$ & $13.6 \%{ }^{* * *}$ & $8.3 \%^{* * *}$ & $4.0 \%{ }^{* * *}$ \\
\hline Governo Federal & $6.9 \%$ & $4.5 \%$ & $7.7 \%{ }^{* *}$ & $5.4 \%$ & $2.9 \%{ }^{*}$ & $2.7 \%{ }^{*}$ \\
\hline Governo Estadual & $2.5 \%^{* * *}$ & $6.2 \%{ }^{* * *}$ & $7.7 \%{ }^{* *}$ & $13.3 \%{ }^{* *}$ & $13.3 \%$ & $16.9 \%{ }^{* * *}$ \\
\hline Clientela privada & $9.1 \%{ }^{*}$ & $7.1 \%$ & $4.9 \%$ & $5.8 \%$ & $5.8 \%$ & $5.8 \%$ \\
\hline Empresas & $6.3 \%$ & $4.7 \%{ }^{* *}$ & $7.0 \%$ & $9.3 \%$ & $11.0 \%{ }^{*}$ & $10.8 \%{ }^{*}$ \\
\hline Total N & 317 & 406 & 514 & 1128 & 590 & 498 \\
\hline
\end{tabular}

Nota: Testes de significância são para as categorias das faculdades de direito selecionadas comparadas a todas as outras. ${ }^{*}$ p. $<0.05,{ }^{* *}$ p. $<0.01,{ }^{* *}$ p. $<0.001$ (bicaudal). 
faculdades de direito que frequentaram. Afinal de contas, os estudantes de elite têm maior probabilidade de trabalharem em grandes escritórios corporativos (ver Tabela 3), de modo que sua falta de satisfação pode ser consequência de onde trabalham, ao invés das disposições que adquiriram na faculdade de direito.

Para investigar essa possibilidade, restringimos a amostra àqueles entrevistados que trabalham em empresas com mais de 100 advogados. Os dados da Figura 2 confirmam que, mesmo dentro desses grandes escritórios de advocacia, a maioria dos graduados de elite continua a expressar níveis mais baixos de satisfação na carreira se comparados aos da quarta categoria - $26 \%$ da elite relata extrema satisfação em comparação com quase a metade $(48 \%)$ daqueles na quarta categoria.

Da mesma forma, descobrimos que os graduados nas dez melhores faculdades de direito são mais propensos a pretender deixar seu trabalho dentro de dois anos, se comparados com a quarta categoria (59\% versus $27 \%$ ). Esses padrões sugerem que a satisfação relativamente menor dos graduados de elite não é

Figura 1. Medidas da satisfação por categoria da faculdade de direito

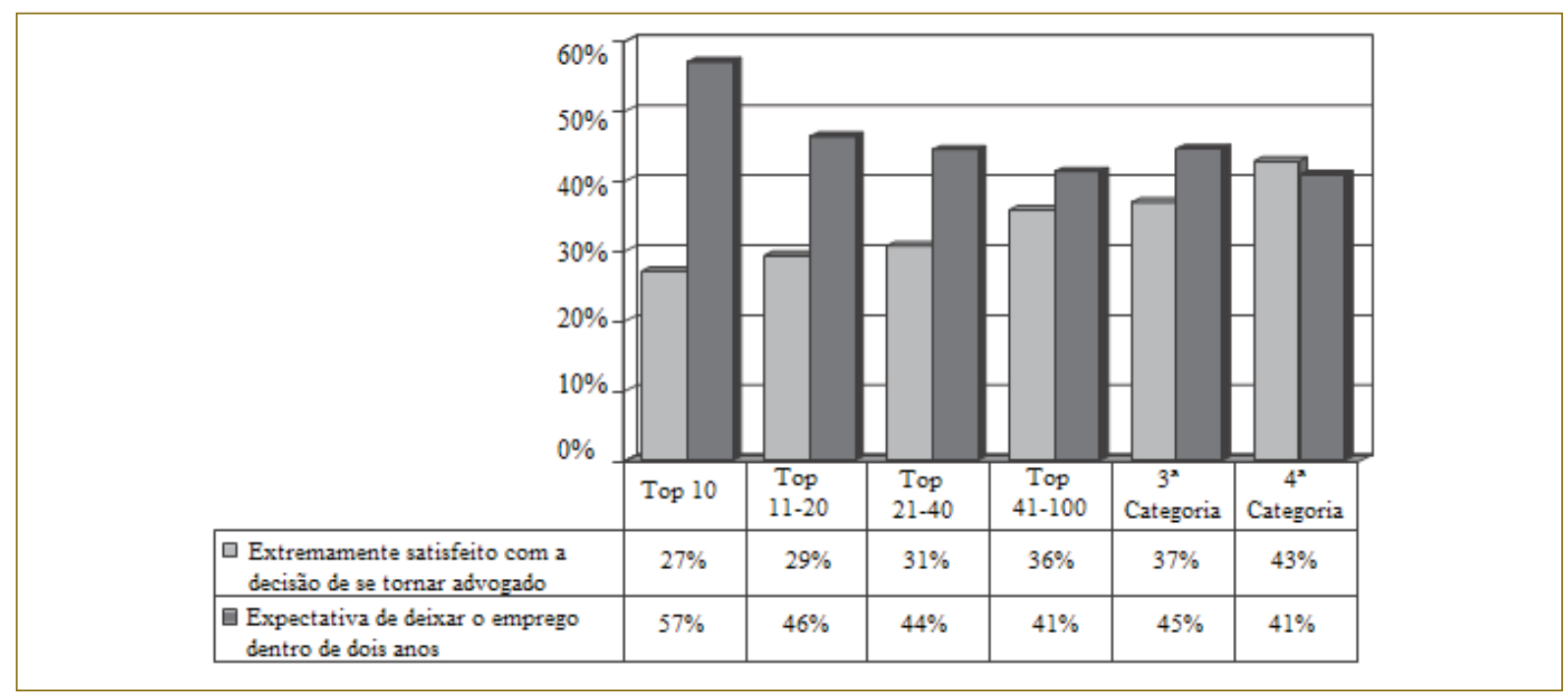

Figura 2. Medidas de satisfação por categoria da faculdade de direito (subamostra de advogados de grandes escritórios (>100)).

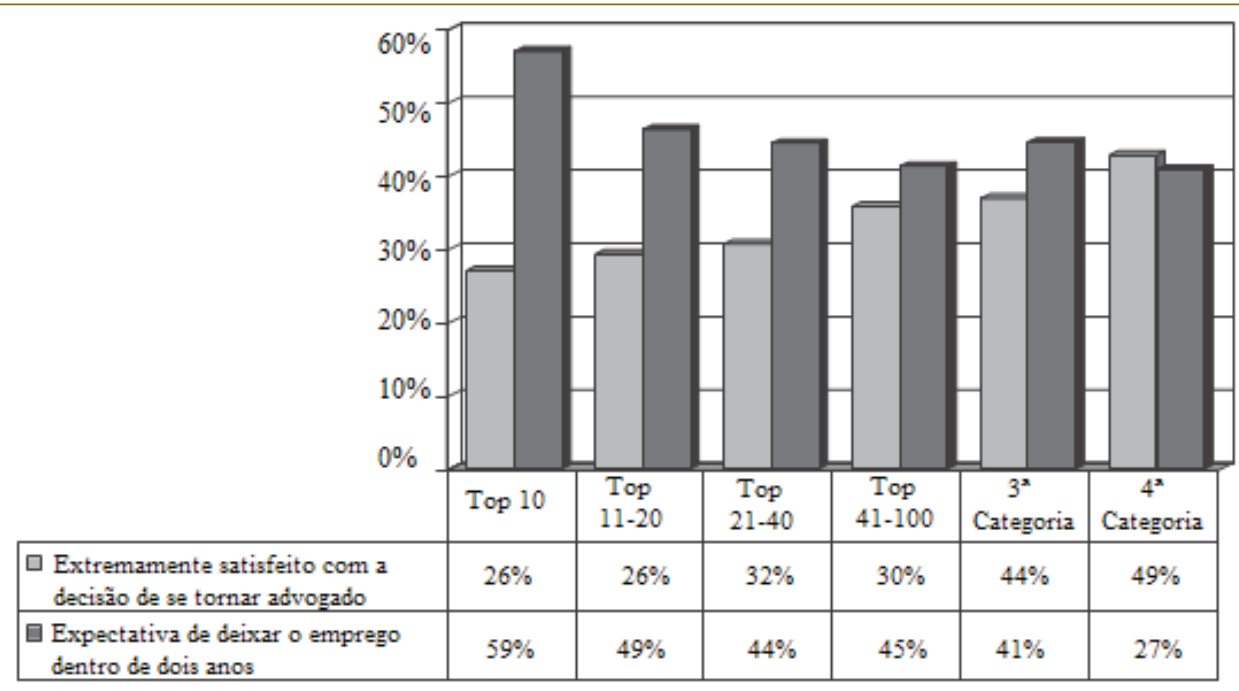


meramente motivada por seus ambientes de trabalho e que há uma relação entre o nível da faculdade de direito e as expressões de satisfação independente do ambiente de trabalho, o que requer uma investigação mais aprofundada.

Ao incorporarmos padrões de estratificação social em nossa análise de satisfação, percebemos que as expressões de contentamento se relacionam claramente à hierarquia das faculdades de direito - e que a atenção a tais hierarquias sociais resolve a aparente tensão entre a satisfação profissional dos advogados e suas intenções de mobilidade. Encontramos um padrão consistente com o modelo de Bourdieu (1998), de acordo com o qual as escolas não apenas desempenham um papel importante na transmissão da reprodução social, mas também são decisivas para apontar as disposições e aspirações que moldam as carreiras dos novos advogados.

Abaixo, desenvolvemos essa abordagem baseando-nos em análises multivariadas, que nos permitem explorar melhor a interação entre as origens sociais, os valores e as credenciais dos advogados em vários contextos de prática.

\section{Satisfação como Processo: Mapeando a Estrutura da Profissão Jurídica}

\subsection{Quadro índices da Satisfação Profissional}

Começamos explorando os determinantes da satisfação no trabalho, em relação aos quais Hull (1999) argumentou serem melhor classificados como um conceito multivalente. Seguindo essa abordagem, conduzimos uma análise fatorial dos 16 medidores de satisfação profissional presentes na Tabela 1, reduzindo-os em quatro fatores; tais fatores foram extraídos usando a análise de componente principal e, depois, salvos como pontuações padronizadas com uma média de 0 e um desvio padrão de $1^{12}$.

O primeiro fator representa "satisfação no ambien-

12 As pontuações alfa baseadas nos itens individuais resultam nas seguintes pontuações: ambiente $=.85$, essência $=.88$, índice social $=.584$ e poder $=.62$. te de trabalho" (contexto de trabalho), e consolida as classificações de reconhecimento recebidas no trabalho, relacionamentos com colegas, controle sobre o trabalho e estabilidade no emprego. 0 fator de "satisfação quanto ao conteúdo do trabalho" reflete o interesse intrínseco em relação às atividades desempenhadas, enquanto o terceiro fator, "satisfação quanto ao valor social" (índice social), diz respeito à relação entre o trabalho e questões sociais mais amplas (diversidade, oportunidades de trabalho pro bono e o valor social). O quarto fator, a "satisfação quanto ao poder" (faixa de poder) é composto por dois itens: satisfação com a remuneração e satisfação com as oportunidades de progressão na carreira. Em seguida, estimamos quatro modelos distintos de satisfação no trabalho - um para cada satisfação quanto ao ambiente de trabalho, quanto ao conteúdo do trabalho, valor social e poder.

A Tabela 4 descreve as médias (Med.) e desvios-padrão (Desv. P.) das variáveis utilizadas em todas as análises ${ }^{13}$. Pouco mais da metade dos entrevistados são do sexo masculino e pouco mais da metade são casados, mas menos de $1 / 3$ tem filhos e apenas $16 \%$ tem mais de 36 anos. $83 \%$ dos entrevistados são brancos e $38 \%$ vivem em grandes áreas metropolitanas (NY, Chicago, DC, Los Angeles, São Francisco e Boston). Os demais 23\% vivem em outras áreas metropolitanas (Atlanta, Houston, Minneapolis e St. Louis); cada região é modelada como uma variável binária, e a categoria excluída representa aqueles que vivem em áreas não-metropolitanas.

Para controlar os efeitos dos ambientes de prática jurídica, utilizamos uma série de variáveis binárias. A medida do tamanho do escritório, por sua vez, baseia-se no número total de advogados emprega$\operatorname{dos}^{14}$. As pequenas empresas privadas (de 2 a 20 ad-

13 Discutimos aqui a estatística descritiva baseada nos quatro modelos de satisfação do MQO, embora a Tabela 4 apresente as médias e desvios-padrão para todas as análises. Favor consultar Dinovitzer et al. (2005) para a distribuição dos entrevistados através destas configurações na amostra como um todo.

14 Enquanto as análises relatadas neste trabalho se baseiam na medida do tamanho do escritório a partir do número de advogados empregados em toda a empresa, todas as análises também foram testadas usando a medida de tamanho do escritório derivada do número de advogados empregados na empresa específica na qual os entrevistados trabalham. Majoritariamente, os resultados 


\begin{tabular}{|c|c|c|c|c|c|c|}
\hline & \multicolumn{2}{|c|}{$\begin{array}{l}\text { Quatro Modelos de } \\
\text { Satisfação }\end{array}$} & \multicolumn{2}{|c|}{$\begin{array}{l}\text { Satisfação } \\
\text { Profissional }\end{array}$} & \multicolumn{2}{|c|}{$\begin{array}{l}\text { Probabilidade } \\
\text { de deixar o } \\
\text { Empregador }\end{array}$} \\
\hline & Med. & Desv. P. & Med. & Desv. P. & Med. & Desv. P. \\
\hline \multicolumn{7}{|l|}{ Demografias e Histórico } \\
\hline Homem & 0.570 & 0.495 & 0.546 & 0.498 & 0.570 & 0.495 \\
\hline Casado & 0.570 & 0.496 & 0.563 & 0.496 & 0.564 & 0.496 \\
\hline Tem filhos & 0.260 & 0.441 & 0.273 & 0.446 & 0.264 & 0.441 \\
\hline Mais de 36 anos & 0.160 & 0.363 & 0.175 & 0.380 & 0.157 & 0.364 \\
\hline Branco & 0.830 & 0.376 & 0.832 & 0.374 & 0.829 & 0.377 \\
\hline Pontuação Socioeconômica do Pai & 60.413 & 18.216 & 60.543 & 18.099 & 60.326 & 18.224 \\
\hline Familiares advogados & 0.201 & 0.401 & 0.202 & 0.401 & 0.200 & 0.400 \\
\hline \multicolumn{7}{|l|}{ Região } \\
\hline $\begin{array}{l}\text { Principais Metrópoles (NY, LA, DC, } \\
\text { Chicago, SF, Boston) }\end{array}$ & 0.380 & 0.485 & 0.380 & 0.485 & 0.377 & 0.485 \\
\hline $\begin{array}{l}\text { Outras grandes metrópoles } \\
\text { Contexto (excluídos os escritórios } \\
\text { privados } 2-20)\end{array}$ & 0.230 & 0.420 & 0.216 & 0.412 & 0.226 & 0.419 \\
\hline Autônomo & 0.020 & 0.147 & 0.034 & 0.181 & 0.022 & 0.146 \\
\hline Escritório Privado 21-100 & 0.140 & 0.349 & 0.125 & 0.331 & 0.142 & 0.350 \\
\hline Escritório Privado 101-250 & 0.090 & 0.289 & 0.077 & 0.266 & 0.091 & 0.288 \\
\hline Escritório Privado 2511 & 0.250 & 0.433 & 0.210 & 0.407 & 0.247 & 0.432 \\
\hline Governo Federal & 0.033 & 0.179 & 0.049 & 0.217 & 0.032 & 0.176 \\
\hline Governo Estadual & 0.081 & 0.273 & 0.112 & 0.316 & 0.081 & 0.273 \\
\hline Clientela Privada & 0.040 & 0.203 & 0.062 & 0.241 & 0.043 & 0.203 \\
\hline Empresas & 0.070 & 0.251 & 0.085 & 0.279 & 0.068 & 0.252 \\
\hline \multicolumn{7}{|l|}{$\begin{array}{l}\text { Prestígio e Performance (excluída } \\
\text { a } 4^{\mathrm{a}} \text { categoria) }\end{array}$} \\
\hline GPA da Faculdade de Direito & 3.296 & 0.344 & 3.279 & 0.348 & 3.294 & 0.344 \\
\hline Top 10 & 0.070 & 0.261 & 0.072 & 0.25 & 0.073 & 0.260 \\
\hline Top $11-20$ & 0.120 & 0.330 & 0.114 & 0.318 & 0.123 & 0.329 \\
\hline Top 21-40 & 0.160 & 0.369 & 0.163 & 0.370 & 0.161 & 0.368 \\
\hline Top 41-100 & 0.320 & 0.466 & 0.331 & 0.471 & 0.320 & 0.467 \\
\hline $3^{\mathrm{a}}$ Categoria & 0.190 & 0.391 & 0.181 & 0.385 & 0.189 & 0.391 \\
\hline Salário $(/ 1,000)$ & 85.547 & 39.336 & 80.910 & 39.165 & 85.296 & 39.207 \\
\hline Percentagem de dívida zero & 0.130 & 0.331 & 0.128 & 0.335 & 0.125 & 0.331 \\
\hline Dívida Alta $\left(75^{\circ}\right.$ percentil $)$ & 0.251 & 0.434 & 0.247 & 0.432 & 0.251 & 0.434 \\
\hline Posições Anterores & 0.300 & 0.458 & 0.321 & 0.467 & 0.302 & 0.459 \\
\hline Consultoria ou bancos de investimento & 0.322 & 0.467 & 0.317 & 0.011 & 0.318 & 0.010 \\
\hline Network com advogados senior ${ }^{\mathrm{a}}$ & 0.639 & 0.480 & 0.627 & 0.011 & 0.624 & 0.011 \\
\hline Satisfação com o contexto professional & -0.026 & 1.016 & - & - & -0.025 & 1.017 \\
\hline Satisfação com a substância de trabalho & 0.011 & 0.999 & - & - & 0.008 & 1.001 \\
\hline Satisfação com o índice social & -0.025 & 0.978 & - & - & -0.028 & 0.982 \\
\hline Satisfação com a faixa de poder & 0.001 & 0.993 & - & - & -0.003 & 0.992 \\
\hline Probabilidade de deixar o empregador & - & - & - & - & 1.464 & 0.499 \\
\hline Satisfação Profissional & - & - & 0.334 & 0.472 & - & - \\
\hline $\mathrm{n}$ de análise & 1485 & & 1899 & & 1467 & \\
\hline
\end{tabular}

${ }^{\mathrm{a}}$ Médias e desvios padrão são calculados pela média dos cinco conjuntos de dados imputados de forma múltipla. 
vogados) foram excluídas da amostra, que representa a maior concentração dos entrevistados (28\%). As empresas médias, de 21-100 advogados, são responsáveis por $14 \%$ dos entrevistados, as grandes empresas (101-250 advogados) por 9\% e 25\% deles trabalham nas megaempresas, com mais de 251 advogados. Encontramos uma menor proporção de entrevistados que trabalham fora da prática privada, sendo $8 \%$ trabalhando para o governo estadual, 3\% para o governo federal e $2 \%$ sozinhos. Menos de $11 \%$ dos entrevistados trabalham nos ambientes públicos não governamentais e com negócios. Evidentemente, agrupar os advogados que atuam na prática privada conforme o tamanho do escritório oculta grande variação quanto ao ambiente de trabalho por exemplo, mesmo entre os mega escritórios com mais de 250 advogados existe uma hierarquia empresarial, de acordo com a lucratividade, associada às participações dos sócios e, ainda, quanto ao tipo de participação na sociedade (por exemplo, advogados de capital e de não capital) (ver, por exemplo, HENDERSON, 2005).

Embora este artigo não possa abordar toda a gama de variação dentro de cada cenário, os agrupamentos empregados nas análises abaixo revelam importantes clivagens na hierarquia entre os advogados que trabalham em empresas privadas.

Nossa análise inclui medidas de status social dos entrevistados, como o prestígio da faculdade de direito e seu desempenho. Incluímos duas medidas sobre o status socioeconômico. A primeira baseia-se no Índice Socioeconômico Internacional (International Social-Economic Index - ISEI) das pontuações de status ocupacional (GANZEBOOM \& TREIMAN, 1996), que varia de 16 a $90^{15}$. A segunda é uma variável binária que indica se algum dos membros diretos da família dos entrevistados é advogado.

foram quase idênticos; quaisquer diferenças substantivamente interessantes são reportadas em notas de rodapé que acompanham a discussão dos resultados.

15 Nos baseamos aqui nas medidas do status ocupacional dos pais, pois cerca de $10 \%$ dos entrevistados relataram que suas mães não trabalhavam na remuneradamente. O status profissional do pai é, portanto, um indicador mais confiável do histórico socioeconômico dos entrevistados.
A categoria da faculdade de direito frequentada é também modelada como uma série de variáveis binárias, tendo a quarta categoria como a categoria de referência ${ }^{16}$.

Um pouco menos de $10 \%$ dos entrevistados frequentaram uma das faculdades do top $10,12 \%$ deles uma das top $20,16 \%$ se formaram em uma das top $21-40$, $32 \%$ em uma das top $41-100,19 \%$ em uma faculdade de terceira categoria e 14\% em alguma das pertencentes à quarta categoria. Nós também incluímos uma medição das GPA finais das faculdades de direito autoreportadas pelos entrevistados, que era originalmente medida a partir de uma escala ordinal de 8 pontos, com incrementos de 0,25. A categoria inferior da escala foi classificada como "inferior a 2.25" e a categoria superior como "3.75-4.0"17.

Atribuímos pontos médios para cada categoria de modo a criar uma variável de GPA contínua e, como indicado na Tabela 4, o GPA médio na amostra é de 3.3. Nós também incluímos uma medida do salário dos entrevistados ${ }^{18}$ (média de 85.547 dólares), que é dividido por mil. Duas medidas sobre a existência de dívidas estão incluídas: primeiro, uma variável binária é usada para representar os $13 \%$ dos entrevistados que declaram dívida zero; depois, outra variável é usada para representar os entrevistados relatando um montante de dívida, que está no quartil superior de todos os entrevistados a relatar qualquer dívida (ou seja, acima de US\$90.000).

Como medida da mobilidade de trabalho anterior dos inquiridos, incluímos uma variável binária para representar aqueles que ocuparam pelo menos uma posição anterior (30\% dos entrevistados) em comparação com aqueles cujo atual trabalho é o primeiro

16 Seguindo a sugestão de Herbert Kritzer, nós também adotamos uma série de interações para explorar se a própria categoria da faculdade de direito estrutura os vários fatores que afetam a satisfação no trabalho e as intenções de mobilidade. Os resultados dessas análises estão descritos no Apêndice $B$.

17 Todos os dados nessa análise foram reportados nessa escala (alguns entrevistados provavelmente converteram seus GPAs de outras escalas para o formato do questionário). Menos de $1 \%$ ( $\mathrm{n}=$ 28) dos entrevistados relataram que não receberam as notas; esses casos foram retirados da análise.

18 Desviantes dos principais resultados com salários relatados de 201.000 ou superior $(n=25)$ foram removidos da análise a partir destes. 
emprego depois da faculdade de direito.

Duas variáveis adicionais estão incluídas de modo a refletir as preferências de carreira e atividades de networking. Como medida das interações dos entrevistados dentro da empresa, incluímos uma variável binária que é igual a 1, caso respondam que se juntam a parceiros ou advogados seniores durante refeições ou se passam seu tempo de lazer com estes; $64 \%$ dos entrevistados relatam esses tipos de atividades de networking.

A fim de explicar as suas preferências de carreira, incluímos uma medida que busca considerar se concebiam uma carreira de negócios juntamente com - ou ao invés da - jurídica; 32\% dos entrevistados responderam que consideravam essa opção. Ambas as variáveis derivam do subconjunto de entrevistados que preencheram o questionário por correio ( $n=2266$ ); estes dados não foram coletados pela pesquisa telefônica $(n=1627)$. A fim de reduzir o potencial viés resultante da supressão adicional de lista de casos, os dados em falta foram preenchidos para estas duas variáveis baseando-se na imputação múltipla (ALLISON, 2002; LITTLE \& RUBIN, 1987; SCHAFER, 1997); apresentamos os resultados das análises baseadas nessas variáveis como modelos separados em cada uma das tabelas abaixo ${ }^{19}$.

Focando no primeiro modelo de cada um dos quatro modelos de regressão de MQO na Tabela 5, encontramos uma série de padrões que são consistentes com a pesquisa anterior: os homens estão mais satisfeitos do que as mulheres com seu ambiente de trabalho ( $b$ $=.139, \mathrm{p}<.01)$ e o indicador social $(b=.172, \mathrm{p}<.001)$, mas estão menos satisfeitos do que as mulheres com a essência do seu trabalho $(b=-.165 ; p<.01)^{20}$.

Vir de uma família na qual o pai trabalha em uma profis-

19 Nos baseamos na NORM (SCHAFER, 1997) para criar cinco conjuntos de dados imputados de forma múltipla. Os dados são imputados pelo uso de outras variáveis no conjunto de dados. Todas as análises são conduzidas em cada conjunto de dados imputados e, em seguida, contamos com NORM para combinar os coeficientes e os erros-padrão para os cinco conjuntos de resultados; são esses resultados combinados que são reportados nas tabelas.

20 Enquanto questões de raça e gênero são incluídas como dimensões importantes nas análises abaixo, nossa discussão enfoca questões de classe social e credenciais, uma vez que esses aspectos da satisfação no trabalho têm recebido menos atenção em pesquisas anteriores. são mais prestigiosa aumenta a satisfação com a essência do trabalho $(b=0.004 ; p<.05)$, o que sugere que se está mais preparado para o trabalho da advocacia se o pai estava envolvido em uma função de maior prestígio.

Quase acidentalmente descobrimos que viver em uma área metropolitana diminui a satisfação (exceto a satisfação com o ambiente de trabalho) (b variando de -.176 a -.249 em cada modelo, $p<.05$ ou mais). Parece, então, que a vida profissional nas grandes cidades - com seu maior custo de vida e deslocamentos mais longos - é, por si só, uma experiência mais desafiadora, já que esse efeito persiste mesmo depois de controlar a prática e as horas trabalhadas.

Os efeitos dos contextos da prática profissional são os seguintes: os que trabalham sozinhos estão mais satisfeitos com o ambiente $(b=.365, p<.05)$ e com o índice social ( $b=.744, p<.001$ ), enquanto os que trabalham em grandes e mega escritórios (100 a 251+ advogados) estão menos satisfeitos com seu ambiente de trabalho (b variando de -.569 a -.620, $\mathrm{p}<.001$ ).

Os advogados das grandes e das mega firmas (100 a $251+$ advogados) também estão mais satisfeitos com a faixa de poder $(b=.211, p<.05)$, refletindo a satisfação em seus altos níveis de remuneração e oportunidades de progressão.

Em contraste, quase todo ambiente fora da prática privada sugere uma maior insatisfação com a faixa de poder (b variando de -.179 para -.641; $p<.05$ ou mais), e cada contexto do setor público está relacionado a um aumento da satisfação com o índice social (b variando .235 a $.658 ; p<.05$ ou mais).

Finalmente, trabalhar em empresas menores de 21 a 100 advogados leva a níveis significativamente mais baixos de satisfação quanto ao valor social dos empregos (b $=-.349, \mathrm{p}<.001$ ), assim como ter se graduado em uma faculdade de direito de terceira categoria $=-.229, p<.01)^{21}$.

21 Baseando-se na medida do tamanho do escritório, também encontramos que os entrevistados nos escritórios de médio porte de 21-100 advogados estão menos satisfeitos com seu ambiente de prática, e que os advogados nos maiores escritórios ( $251+$ ) obtém um bônus adicional, expresso como uma maior satisfação com o índice social. A análise baseada no tamanho do escritório também indica que, mesmo controlando para networking e aspirações de carreira, advogados nos 
O salário, como esperado, é uma previsão positiva de satisfação em relação a faixa de poder $(b=.010 ; p$ $<.001$ ). Descobrimos que um aumento de US\$100.000 no salário leva a um crescimento do desvio padrão neste aspecto da satisfação, enquanto um acréscimo de US\$100.000 em salário leva a um aumento de três desvios padrão na satisfação quanto à essência do trabalho $(b=.003 ; p<.05)$.

Mas mais inesperada é a descoberta de que os entrevistados com um GPA mais alto também estão mais satisfeitos com a faixa de poder $(b=.211 ; p<.001)$; esta relação entre GPA e satisfação quanto à faixa de poder sugere que aqueles que ganharam notas mais altas se percebem em uma faixa mais rápida e estão felizes por lá estarem. Também descobrimos que a existência de dívida geralmente não está relacionada à satisfação no trabalho.

Os dados das quatro equações do Modelo 2 sugerem que as redes de relações sociais desempenham um papel importante na satisfação dos advogados quanto ao seu ambiente de trabalho ( $b=.281, p<.05$ ), quanto a essência do seu trabalho $(b=.278, p<.05$ ) e o índice social ( $b=.109, p<.05)$, sugerindo que as relações com mais advogados sênior resultam em melhor ou, pelo menos, em mais interessantes atribuições de trabalho.

Como discutiremos mais à frente, esta conclusão tem implicações interessantes para os graduados de faculdades de direito de elite, que - neste momento de suas carreiras - não parecem estar investindo tanto quanto outros nas redes sociais. Embora a introdução dessas variáveis modere levemente os efeitos do salário e o tamanho da empresa em dois modelos, os principais padrões de signo e significado são geralmente inalterados quanto às quatro medidas de satisfação no trabalho.

A partir de nossa abordagem teórica esperávamos encontrar uma relação entre o tipo de faculdade de direito e a satisfação no trabalho. No entanto, nenhum dos modelos apresentados na Tabela 5 mostra qualquer associação entre a categoria da faculdade

maiores escritórios ( 251 + advogados) continuam a ser significativamente mais satisfeitos com a faixa de poder. de direito e quaisquer das medidas de satisfação ${ }^{22}$.

Podemos ficar tentados a concluir, a partir das análises acima, que a satisfação na carreira de advogado não está relacionada ao contexto social e que, embora as credenciais das faculdades de direito possam ser importantes para a obtenção de empregos (ver HEINZ et al., 2005), os efeitos dessas credenciais se uniformizam no momento em que os advogados entram nos seus ambientes de prática. Há outras razões para questionar essa conclusão.

Em particular, a grande importância dada ao ambiente de trabalho nos quatro modelos de satisfação pode mascarar relações mais sutis. Para analisar mais a fundo, consideremos duas medidas adicionais de satisfação que proporcionam uma perspectiva mais ampla sobre a carreira dos advogados: o contentamento com a escolha de uma carreira jurídica e as intenções de mobilidade profissional.

\subsection{Explorando a Satisfação na Carreira}

Começamos por investigar o que determina a satisfação dos entrevistados em relação à sua decisão de se tornarem advogados. Ao invés de focar em indicadores específicos de satisfação no trabalho - que, como os modelos anteriores sugeriram, são condicionados pelo ambiente imediato - concentrar o foco na satisfação com a escolha da atividade profissional fornece uma indicação mais ampla quanto às estratégias e preferências de carreira.

Pesquisas anteriores já sugeriram vínculos entre histórico social, aspirações (por exemplo, SERON, 1996)

22 Em análises separadas (em arquivo com autores), modelamos as quatro regressões de satisfação com as categorias das faculdades de direito apenas do primeiro passo no modelo. Descobrimos que os graduados das dez primeiras faculdades de direito são significativamente menos satisfeitos com seu ambiente de trabaIho ( $p<.05$ ou mais), com a satisfação decrescente à medida que aumenta a categoria da faculdade de direito. Graduados de todas as faculdades de direito, exceto as dez primeiras, estão significativamente menos satisfeitos com o índice social ( $p<.05$ ou mais). Também vimos que os graduados das 10 melhores faculdades de direito são significativamente mais satisfeitos com a faixa de poder em comparação com os graduados das faculdades de quarto nível ( $p<0,05$ ou melhor), e a satisfação com a faixa de poder aumenta com a categoria da faculdade. Como descrevemos no texto, no entanto, os efeitos dos ambientes da prática (entre outros) moderam essas relações iniciais. 
Tabela 5. Quatro Modelos MQO de Satisfação Profissional $(n=1.485)$

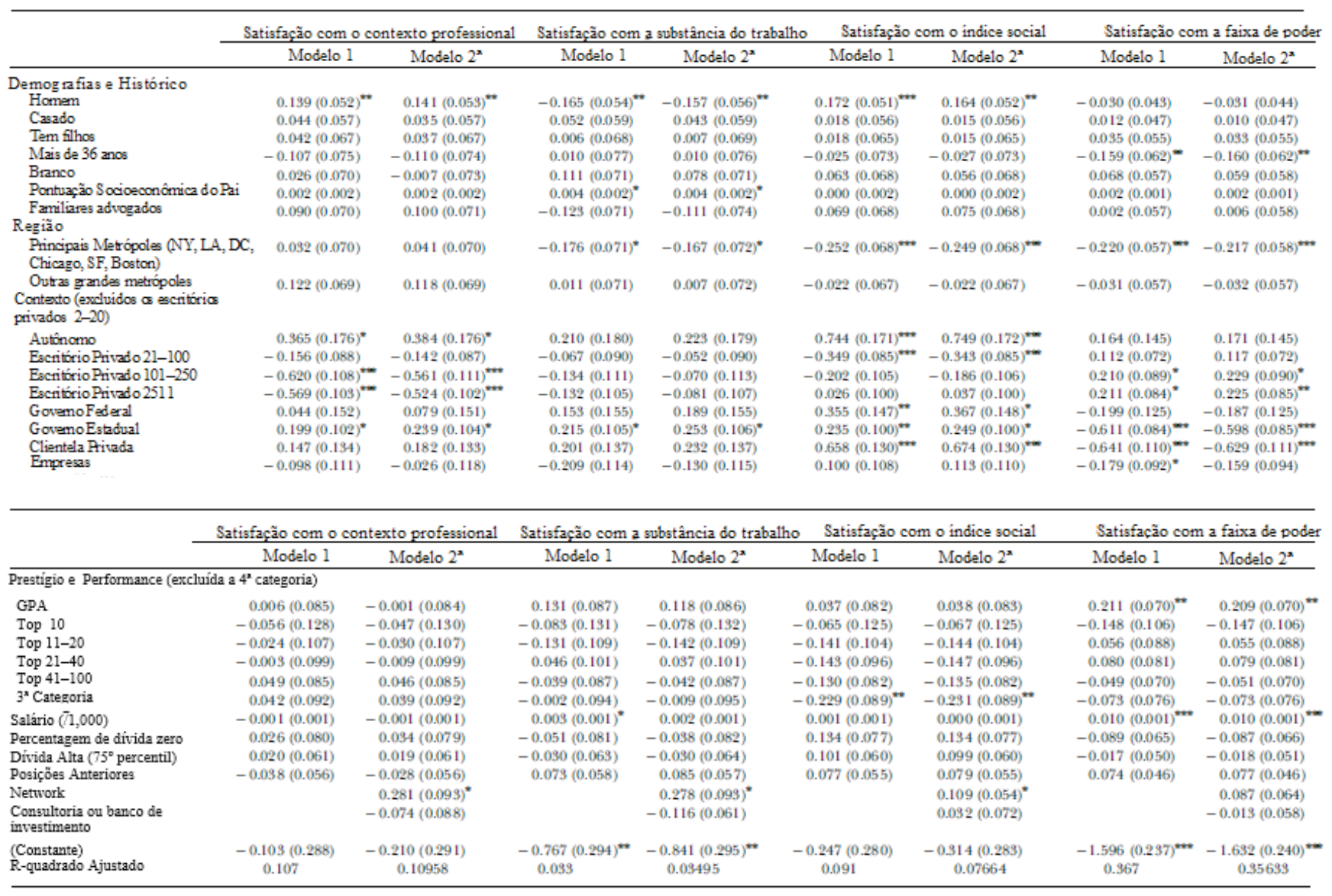

aModelo 2 exibe resultados de múltiplos dados imputados. Favor consultar o texto para discussão dos procedimentos sobre dados ausentes.

Nota: Os números em parênteses são os erros padrão.

${ }^{*} p<.05,{ }^{* *} p<.01,{ }^{* * *} p<.001$ (bicaudal).

e os valores do trabalho (MCCLELLAND 1990, JACOBS ET AL., 1991, JOHNSON 2001, 2002, HALABY 2003). E o trabalho de Bourdieu tem fornecido uma visão adicional sobre os papéis das faculdades nesse processo. De fato, Bourdieu argumenta que é na escola que os alunos "adquirem não só as maneiras e o estilo, certos que estes são os sinais mais seguros de nobreza, mas também a representação de que tais sinais os conduzirão (...) para as ambições mais sublimes e empresas mais prestigiadas" (BOURDIEU, 1989, p. 112). A satisfação profissional, então, é o produto de expectativas e circunstâncias, que são, elas mesmas, moldadas pelo histórico social dos indivíduos.

Nas análises abaixo, extraímos as respostas à pergunta "O quão satisfeito você é com a decisão de estudar direito?". Elas foram fornecidas com base em uma escala de cinco pontos, variando de 1 ("Extremamente Satisfeito") a 5 ("Extremamente Insatisfeito"). Uma vez que a distribuição das respostas é desviada para o fim "satisfeito" do espectro (35\% relataram que estavam "extremamente satisfeitos", enquanto um adicional de $44 \%$ indicou que estava "moderadamente satisfeito"), focamos aqui nos entrevistados que relataram estar extremamente satisfeitos com a decisão de se tornarem advogados ${ }^{23}$. A satisfação, portanto, é

23 Nós modelamos uma regressão adicional para prever a probabilidade de expressar insatisfação com a decisão de se tornar advogado (o que representou 13,3\% dos entrevistados). Os resultados foram geralmente consistentes com os descritos abaixo, com a adição da constatação de que os homens têm probabilidades significativamente menores de expressar insatisfação com a sua 
modelada como uma variável binária, e novamente empregamos a regressão logística, com base no mesmo conjunto de variáveis descritas na Tabela 5.

Os resultados desta análise confirmam algumas de nossas descobertas anteriores e sugerem padrões adicionais (ver Tabela 6). No primeiro modelo, verificamos que os fatores demográficos relacionados à satisfação com a carreira refletem uma determinada etapa da vida: os entrevistados com filhos são mais propensos a responder que estão extremamente satisfeitos com sua decisão de se tornarem advogados $\left(b=.280, e^{b}=1.323 ; p<.05\right)$, assim como os entrevistados com mais de 36 anos ( $\left.b=.329, e^{b}=1.89, p<.05\right)$.

Esta demografia dos entrevistados - aqueles que estão começando suas carreiras mais tarde na vida, ou que têm uma família para sustentar - é claramente correspondente com a sua escolha de buscar uma carreira jurídica. Encontramos também uma relação positiva e significativa entre o estado ocupacional do pai e a satisfação com a carreira $\left(b=.008, e^{b}=1.008\right.$, $p<.05)$. Este efeito é difícil de explicar, mas pode ser que os filhos de pais com maiores status saibam melhor o que esperar das profissões jurídicas.

Consideramos também a relação entre o ambiente profissional e a satisfação com a carreira, recorrendo novamente a pequenos escritórios particulares ( 2 a 20 advogados) como categoria de referência.

Os dados indicam que os profissionais que trabalham sozinhos estão tão satisfeitos quanto aqueles das pequenas empresas, quanto à decisão pela carreira jurídica. Para os advogados que trabalham em escritórios de advocacia privados, o padrão é claro: quanto maior a empresa, menores as expressões de satisfação na carreira, com a satisfação diminuindo, à medida que o tamanho da empresa aumenta (b variando de -.400 a -.864; $p<.05$ ou mais). Fora da prática privada, verificamos que os entrevistados que trabalham no governo estadual estão significativamente mais satisfeitos com sua escolha de carreira (b $=.578, \mathrm{~b}=1.783, \mathrm{p}<.001)$.

Medidas de prestígio e desempenho também estão

escolha de carreira do que as mulheres. relacionadas com a satisfação profissional. Os efeitos referentes à categoria da faculdade de direito reforçam os padrões relacionados aos cenários da prática profissional: os advogados graduados em faculdades de direito de elite estão significativamente menos satisfeitos com sua decisão de se tornarem advogados. Quando comparados com os graduados de faculdades de quarta categoria, os graduados das dez melhores faculdades têm probabilidades mais baixas de responder que estão extremamente satisfeitos ( $b=$ $-.646, \mathrm{eb}=.524 ; \mathrm{p}<.05)$, seguidos pelos graduados das vinte melhores faculdades $\left(b=-.465, e^{b}=.628 ; p<.05\right)$.

Apesar de não atingir significância ao nível de .05, também percebemos que os graduados das 40 melhores faculdades expressam níveis mais baixos de satisfação, em comparação com os seus colegas da quarta categoria ( $b=0.349$, $\left.e^{b}=.705 ; p=.06\right)$; os entrevistados que se formam em todas as demais categorias relatam níveis de satisfação que não são diferentes dos entrevistados que se formaram em faculdades de quarta categoria.

Finalmente, encontramos que o salário está positiva e significativamente relacionado com as probabilidades de estar extremamente satisfeito com a decisão de se tornar advogado $\left(b=.009, e^{b}=1.009 ; p<.001\right)$.

Incluímos os efeitos do networking e das aspirações no segundo modelo na Tabela 6 . Verificamos que os novos advogados que se relacionam com seniores têm 1,29 vezes a probabilidade de expressar fortes sentimentos de satisfação com sua escolha da profissão, o que aponta para o padrão elitizado da carreira. Os entrevistados que optaram por seguir carreiras em bancos de investimento ou consultoria, demonstraram estar menos satisfeitos com a decisão de se tornarem bacharéis em direito $\left(b=-.276, e^{b}=.759\right.$; $\mathrm{p}<.05$ ), o que aponta para um entusiasmo diminuído sobre suas escolhas profissionais.

Esta análise confirma a importante relação entre as medidas de estratificação social e as expressões de satisfação. Descobrimos que os entrevistados com as credenciais mais elitizadas - os graduados das meIhores faculdades de direito que trabalham nos ambientes mais prestigiados - são os menos satisfeitos com a escolha profissional. Por outro lado, os gradu- 
ados das faculdades de direito menos seletivas, e que trabalham em ambientes menos prestigiosos (e com menores remunerações), são os que mais expressam extrema satisfação com a escolha da profissão.

Não há dúvida de que para muitos dos graduados das faculdades de categorias inferiores, a própria entrada na profissão jurídica faz parte de um projeto de mobilidade ascendente. No entanto, os padrões de satisfação observados nesta análise legitimam e reforçam um sistema de estratificação que coloca certos graduados em direito em contextos específicos de prática profissional e cujas faculdades de direito desempenham um papel fundamental na reprodução desta hierarquia.

\subsection{Satisfação Profissional e Planos para Mobilidade Profissional}

Exploramos ainda os sentimentos de satisfação, levando em conta as intenções dos entrevistados em deixar seus postos de trabalho.

Expressões relativas à intenção de deixar o emprego demonstram insatisfações relativas e incertezas quan- to aos passos a dar na carreira, mas também indicam o padrão de movimento e os ajustes que as pessoas fazem enquanto constroem suas trajetórias profissionais. Embora a investigação anterior tenha se inclinado a compreender a mobilidade de trabalho como uma manifestação de insatisfação, o que, certamente é verdade, defendemos que esta pesquisa deve também levar em conta as características estruturais da mobilidade.

A mobilidade pode levar alguém a um caminho mais lucrativo ou de prestígio, ou pode ser um movimento estimulado por um sentimento de que as chances de sucesso podem ser melhores em um ambiente diferente, porém menos prestigioso. De qualquer maneira, a compreensão da mobilidade requer a compreensão a respeito de onde o indivíduo veio e para onde ele pode estar indo, e cujas intenções de se mudar atuam como indicadores - e aspectos - do processo de classificação.

Nós modelamos as intenções dos entrevistados de deixar o emprego usando a regressão logística multinominal para explorar os fatores que influenciam a probabilidade de tais intenções, dentro de cada um dos quatro prazos diferentes: 1) atualmente ou em menos de um ano; 2) dentro de 1 a 2 anos; 3) dentro

Tabela 6. Modelos de Regressão Logística de Satisfação com a Decisão de se Tornar Advogado $(n=1.904)$

\begin{tabular}{|c|c|c|c|c|c|c|}
\hline & \multicolumn{3}{|c|}{ Modelo 1} & \multicolumn{3}{|c|}{ Modelo $2^{2}$} \\
\hline & \multicolumn{2}{|c|}{$\mathrm{b}$} & \multirow[t]{2}{*}{$\operatorname{Exp}(b)$} & \multicolumn{2}{|c|}{$\mathrm{b}$} & \multirow[t]{2}{*}{$\operatorname{Exp}(b)$} \\
\hline Demografias e Histórico & & & & & & \\
\hline Homem & -0.011 & $(0.105)$ & 0.989 & 0.009 & $(0.107)$ & 1.009 \\
\hline Casado & -0.099 & $(0.115)$ & 0.905 & -0.108 & $(0.115)$ & 0.897 \\
\hline Tem pelo menos um(a) filho(a) & 0.280 & $(0.130)^{*}$ & 1.323 & 0.287 & $(0.131)^{*}$ & 1.333 \\
\hline Mais de 36 anos & 0.329 & $(0.137)^{*}$ & 1.389 & 0.341 & $(0.138)^{*}$ & 1.407 \\
\hline Branco & -0.162 & $(0.136)$ & 0.851 & -0.199 & $(0.138)$ & 0.819 \\
\hline Pontuação socioeconômica do pai & 0.008 & $(0.003)^{*}$ & 1.008 & 0.008 & $(0.003)^{*}$ & 1.008 \\
\hline Familiares advogados & -0.025 & $(0.136)$ & 0.975 & -0.031 & $(0.138)$ & 0.970 \\
\hline \multicolumn{7}{|l|}{ Região } \\
\hline Principais metrópoles (NY, LA, DC, Chicago, SF e Boston) & -0.036 & $(0.133)$ & 0.965 & -0.021 & $(0.134)$ & 0.979 \\
\hline Outras grandes metrópoles & -0.001 & (0.139) & 0.999 & -0.001 & $(0.140)$ & 0.999 \\
\hline \multicolumn{7}{|l|}{ Contexto (excluidos os escritórios privados 2-20) } \\
\hline Autônomo & 0.393 & $(0.280)$ & 1.481 & 0.439 & $(0.282)$ & 1.551 \\
\hline Escritório privado 21-100 & -0.400 & $(0.185)^{*}$ & 0.670 & -0.377 & $(0.186)^{*}$ & 0.686 \\
\hline Escritório privado $101-250$ & -0.582 & $(0.235)^{*}$ & 0.559 & -0.517 & $(0.238)^{*}$ & 0.596 \\
\hline Escritório privado $251+$ & -0.864 & $(0.216)^{4+*}$ & 0.422 & -0.809 & $(0.218)^{4+4}$ & 0.445 \\
\hline Govemo Federal & 0.129 & $(0.247)$ & 1.138 & 0.177 & $(0.249)$ & 1.194 \\
\hline Govemo Estadual & 0.578 & $(0.175)^{44-4}$ & 1.783 & 0.617 & $(0.177)^{404 *}$ & 1.854 \\
\hline Clientela privada & 0.342 & $(0.223)$ & 1.408 & 0.369 & $(0.226)$ & 1.447 \\
\hline Empresas & -0.287 & $(0.205)$ & 0.751 & -0.174 & $(0.211)$ & 0.840 \\
\hline
\end{tabular}


Tabela 6. (Continuação)

\begin{tabular}{|c|c|c|c|c|c|c|}
\hline & \multicolumn{3}{|c|}{ Modelo 1} & \multicolumn{3}{|c|}{ Modelo $2^{2}$} \\
\hline & \multicolumn{2}{|c|}{$\mathrm{b}$} & \multirow[t]{2}{*}{$\operatorname{Exp}(b)$} & \multicolumn{2}{|c|}{$\mathrm{b}$} & \multirow[t]{2}{*}{$\operatorname{Exp}(b)$} \\
\hline \multicolumn{5}{|c|}{ Prestigio e Performance (excluida a $4^{x}$ categoria) } & & \\
\hline GPA & 0.220 & $(0.164)$ & 1.246 & 0.198 & $(0.165)$ & 1.219 \\
\hline Top 10 & -0.646 & $(0.262)^{*}$ & 0.524 & -0.618 & $(0.265)^{*}$ & 0.539 \\
\hline Top 11-20 & -0.465 & $(0.215)^{*}$ & 0.628 & -0.477 & $(0.216)^{*}$ & 0.621 \\
\hline Top $21-40$ & -0.349 & $(0.190)$ & 0.705 & -0.364 & $(0.192)$ & 0.695 \\
\hline Top 41-100 & -0.056 & $(0.158)$ & 0.946 & -0.053 & $(0.160)$ & 0.948 \\
\hline $3^{x}$ Categoria & -0.104 & $(0.177)$ & 0.901 & -0.101 & $(0.178)$ & 0.904 \\
\hline Salário $(/ 1,000)$ & 0.009 & $(0.002)^{4+4-4}$ & 1.009 & 0.009 & $(0.002)^{404-4}$ & 1.009 \\
\hline Percentagem de divida zero & -0.148 & $(0.158)$ & 0.862 & -0.118 & (0.159) & 0.889 \\
\hline Divida Alta ( $75^{\circ}$ percentil) & 0.078 & $(0.122)$ & 1.081 & 0.082 & $(0.123)$ & 1.086 \\
\hline Posições Anteriores & -0.156 & $(0.110)$ & 0.855 & -0.139 & $(0.111)$ & 0.870 \\
\hline Network & & & & 0.282 & $(0.133)^{*}$ & 1.326 \\
\hline Consultoria ou banco de investimento & & & & -0.276 & $(0.134)^{*}$ & 0.759 \\
\hline Constante & -2.083 & $(0.565)^{4+4 * *}$ & 0.125 & -2.138 & $(0.575)^{404-4}$ & 0.118 \\
\hline Probabilidade -2 log & 2332.608 & & & 2318.851 & & \\
\hline Nagelkerke R-quadrado & 0.062 & & & 0.071 & & \\
\hline
\end{tabular}

aModelo 2 exibe resultados de múltiplos dados imputados. Favor consultar o texto para discussão dos procedimentos sobre dados ausentes.

Nota: Os números em parênteses são os erros padrão.

${ }^{\star} p<.0 .05,{ }^{\star *} p<.0 .01,{ }^{\star \star *} p<.0 .001$ (bicaudal).

de 3 a 5 anos; 4) em mais de 5 anos.

Os modelos de regressão logística multinominal calculam as probabilidades logarítmicas de estar numa determinada categoria da variável dependente, em relação a alguma categoria de referência da variável dependente (LONG, 1997). Nesse sentido, contamos com a quarta categoria - esperando permanecer com seu empregador atual por pelo menos cinco anos como a categoria de referência.

As regressões foram modeladas a partir do conjunto de variáveis independentes descrito acima, com uma exceção: para controlar a possibilidade de que as intenções de busca de outras oportunidades estejam relacionadas às condições de trabalho, esses modelos também incluem controles sobre a satisfação profissional, baseados nas quatro medidas de satisfação profissional acima descritas.

Embora os resultados sejam complexos, os padrões são bastante consistentes em todas as categorias da variável dependente; como resultado, pormenorizamos abaixo as principais descobertas e padrões, com os resultados completos exibidos na Tabela 7 .

Fatores demográficos são importantes previsões a respeito das intenções de busca de emprego. Em comparação com os entrevistados que esperam permanecer em seu emprego por mais de cinco anos, os homens tem probabilidades significativamente menores do que as mulheres de pensar em deixar seu empregador dentro de um ano $\left(b=-0.573, e^{b}=0.564, p<.01\right)$, assim como os entrevistados com filhos $\left(b=-0.571, e^{b}=0.565\right.$, $p<.05)$ e aqueles que informaram seu status racial ou étnico como branco $\left(b=-0.530, e^{b}=0.589, p<.05\right)$.

Notamos também que viver em uma cidade grande resulta em um significativo aumento na intenção de procurar um novo emprego. Os entrevistados que vivem nas principais áreas metropolitanas têm mais que o dobro da probabilidade de desejarem deixar seu posto de trabalho dentro de dois anos, se comparados aos entrevistados que vivem em áreas não metropolitanas $\left(b=0.754, e^{b}=2.126, p<.001\right)$.

Estes modelos também evidenciam importantes padrões de intenção de mobilidade que estão relacionados com a estratificação social. Entrevistados trabaIhando nos maiores escritórios privados de advocacia e graduados nas faculdades de direito de elite tem maior probabilidade de relatar que pretendem deixar seus cargos nos próximos cinco anos. Por exemplo, os entrevistados que trabalham em mega escritórios (mais de 251 advogados) tem duas vezes maior probabilidade de pensar em deixar seu empregador dentro de cinco anos do que os entrevistados que trabalham em pequenos escritórios privados (de 2 a 20 advoga- 
dos) ( $\left.b=0.831 e^{b}=2.295, p<.01\right)^{24}$. Padrão semelhante quanto à maior intenção de mobilidade surge entre os entrevistados que atuam em posições de prestígio no governo federal $\left(b=1.505, e^{b}=4.505, p<.01\right)$.

Constatamos também que os graduados provenientes das dez melhores faculdades de direito tem 2,4 vezes maior probabilidade de deixarem o cargo atual dentro de cinco anos, em comparação com os graduados das faculdades de quarta categoria ( $b=0.869$, $\left.\mathrm{e}^{\mathrm{b}}=2.385, \mathrm{p}<.05\right)$.

De fato, em todos os modelos, os graduados provenientes das dez melhores faculdades têm maiores probabilidades de relatar intenções de mobilidade do que os graduados de faculdades de quarta categoria.

Finalmente, boas notas na faculdade de direito diminuem significativamente a pretensão de procurar um novo emprego, dentro de um período de cinco anos. O que confirma a descoberta anterior, de que os bacharéis que obtiveram notas mais altas percebem que estão investindo em algo e, portanto, estão comprometidos em alcançar suas metas.

Também modelamos o mesmo conjunto de regressões multinominais com o acréscimo de controles sobre networking e aspirações de carreira, e os resultados são apresentados no Apêndice A. Essas variáveis não produziram previsões significativas de intenções de mobilidade e não alteraram substancialmente o signo ou o significado das variáveis independentes, nos modelos originais.

É importante notar que essas relações entre as credenciais da faculdade de direito, os ambientes de prática profissional e as intenções de mobilidade de trabalho mantem até mesmo o controle de medidas de satisfação. Conforme indicado na Tabela 7, todas as quatro medidas de satisfação profissional são significativas e todas afetam e diminuem as intenções de deixar o cargo atual.

No entanto, apesar dessas medidas de satisfação

24 Ao basear-se na medida de ambiente com base no tamanho do escritório, verificamos que não há relação significativa entre o tamanho do escritório e as intenções de deixar a empresa. Nestes modelos, o efeito para as dez melhores faculdades de direito continua a ser o mesmo relatado na Tabela 7, no entanto. sobre o local de trabalho, continuamos a encontrar uma forte relação entre estratificação social e satisfação. Em suma, essas conclusões indicam que a relação entre estratificação e satisfação profissional não é o resultado das condições de trabalho dos advogados, mas sim expressões das expectativas e aspirações que decorrem de posições particulares dentro do espaço social (ver, em geral, Bourdieu, 1987).

\section{Síntese}

A partir das medidas quanto à satisfação no trabalho, essas análises multivariadas têm fornecido conhecimento sobre a relação entre classe social e satisfação.

Verificamos que, enquanto as medidas de classe social afetam as variações em certos tipos de satisfação no trabalho (contexto, substância, índice social e faixa de poder), essas formas de satisfação são melhor explicadas analisando demograficamente os bacharéis em direito e as colocações nas quais esses graduados trabalham. Por outro lado, as medidas quanto à satisfação na carreira e às intenções de mobilidade estão claramente relacionadas aos padrões de estratificação social.

As análises revelam que os bacharéis mais satisfeitos com as suas escolhas de carreira graduaram-se nas faculdades menos seletivas e trabalham em cargos menos prestigiosos, legitimando a hierarquia na qual os mais privilegiados são aqueles que atingem as posições de alto prestígio e salário, dentre as profissões jurídicas. Similarmente, os bacharéis menos comprometidos em permanecer nos cargos que ocupam, são aqueles que têm mais opções: graduados nas melhores faculdades de direito, trabalham em grandes bancas advocatícias ou em altos postos do governo federal.

Em suma, esses padrões reforçam uma estrutura da profissão por meio da qual bacharéis provenientes das faculdades menos reconhecidas continuam ocupando posições menos prestigiosas e pior remuneradas. 0 efeito para as dez melhores escolas continua o mesmo que aquele mencionado na Tabela 7, com expressões de satisfação tendo um papel chave nesse processo. 
6.1 Modelos quanto ao papel da satisfação e insatisfação

As análises que apresentamos fornecem evidências convincentes sobre a relação entre estratificação e satisfação. Como sustentamos acima, essa relação é produzida não apenas por estruturas externas de dominação, mas internalizada através das expectativas individuais. Enquanto esses padrões ficam evidentes nas análises quantitativas acima citadas, a internalização das estruturas hierárquicas só é claramente re- velada por meio do estudo das biografias individuais (veja genericamente Dezalay e Garth 2002).

Na próxima sessão, nós ilustramos com entrevistas em profundidade, realizadas com os participantes da pesquisa, nas quais eles contam como encontraram seus empregos, descrevem suas práticas e vida profissional e discutem suas expectativas para o futuro. Esses relatos revelam as formas pelas quais os indivíduos dão sentido às suas vidas e encontram

Tabela 7. Regressão logística Multinominal das Intenções de Deixar o Empregador (comparada àqueles que pretendem fazê-lo em 5 anos ou mais)

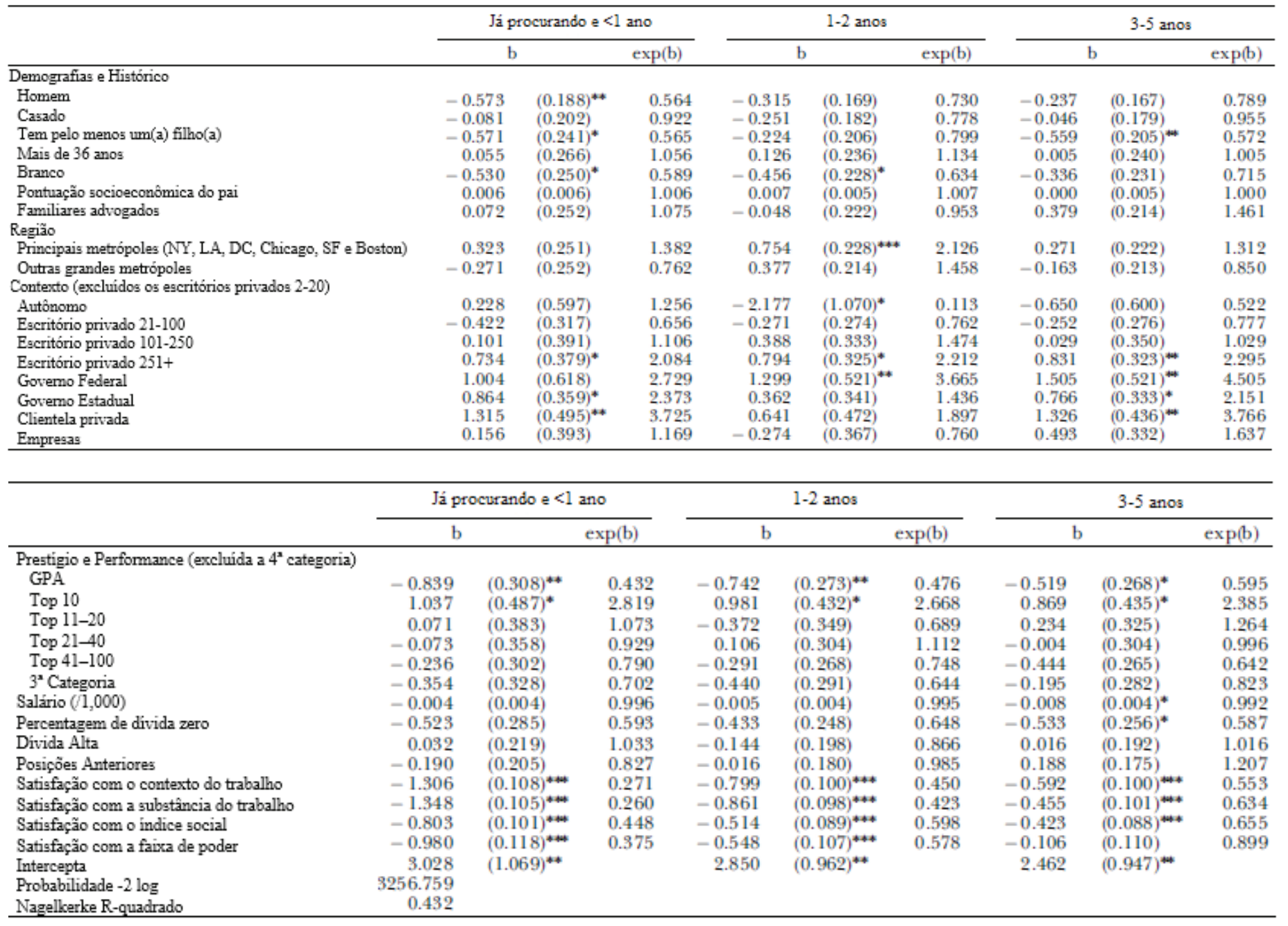

Nota: Os números em parênteses são os erros padrão.

${ }^{\star} p<.0 .05,{ }^{\star *} p<.0 .01,{ }^{* *} p<.0 .001$ (bicaudal). 
satisfação nas posições que ocupam (Lamont, 2000) e também são mecanismos por meio dos quais a estratificação é reproduzida e legitimada.

A discussão abaixo constrói as seis maiores categorias de bacharéis em direito, baseado nas camadas das faculdades que eles frequentaram ${ }^{25}$; essa discussão é exploratória, informada pelos achados discutidos acima e pelas estatísticas fornecidas na Tabela 8 e em tabelas anteriores.

Esses agrupamentos pretendem fornecer uma primeira aproximação quanto ao tipo de pessoa que se forma em diferentes faculdades de direito, e são construídos a partir da compreensão básica de que quanto melhor a faculdade, mais possivelmente os bacharéis provenham de experiências privilegiadas. Entretanto, isso se amplia ao incluir uma série de fatores que surgem fora da classe social, mas são reforçados por ela.

Ao construir essas análises, mostramos explicitamente o quadro teórico elaborado por Bourdieu, fundado em dois conceitos centrais, que possibilitam a compreensão de como a classe social é reproduzida. Um é a noção da habilidade para jogar o jogo - por essa perspectiva, o sucesso na carreira depende da habilidade de controlar algumas regras do jogo; entretanto, a chave não está tanto em aprender as regras do jogo, mas antecipar os passos que fornecerão as oportunidades durante a partida.

Como Bourdieu (1998) explica, os indivíduos que estão bem socializados em um campo particular têm tato para o jogo, pois eles sabem no que devem investir e como colocarem-se e, como bons jogadores de tênis, posicionam-se não onde a bola está, mas onde estará (Bourdieu 1998: 79). É importante notar que, para Bourdieu, esses movimentos e estratégias não são conscientes.

Ter tato para o jogo é tê-lo sob a pele; é ter noção da história do jogo. Enquanto um mau jogador

25 Nos baseamos na classificação fornecida pelo US News \& World Report, mas nossa abordagem é focada na compreensão de que a relação entre efeitos na carreira e credenciais da faculdade; que a hierarquia pode divergir, em alguma medida, das classificações produzidas pela US News. está sempre fora do tempo, sempre muito adiantado ou muito atrasado, o bom jogador é aquele que antecipa, que está à frente. Como consegue estar à frente? Por que tem as tendências imanentes do jogo em seu corpo, em um estado incorporado: encarna o jogo (Bourdieu 1998: 80-81).

De modo semelhante, os bacharéis em direito que estão construindo as suas carreiras estão jogando um jogo, e aqueles que têm sucesso antecipam o movimento correto no momento correto. Intenções de mudar de função e expressões de satisfação com o trabalho, então, são parte desse processo, sugerindo algumas das estratégias que esses novos bacharéis estão utilizando.

Essas estratégias também estão relacionadas às preferências individuais e às disposições, que são melhor compreendidas por meio do conceito de Bourdieu de transformar a necessidade em virtude - sob essa perspectiva, as aspirações individuais e motivações não são construídas no vácuo.

Antes, Bourdieu sustenta que os indivíduos ajustam as suas disposições ao conjunto das possibilidades disponíveis para eles, avaliando aquelas a alcançar e excluindo as que não são alcançáveis. Em outras palavras, as condições dentro das quais as pessoas vivem engendram aspirações e práticas objetivamente compatíveis com os requisitos objetivos. Portanto, as práticas mais improváveis são excluídas como impensáveis, sem exame profundo, ou ao custo de negação dupla, o que leva os agentes a fazerem da necessidade uma virtude, ou seja, recusar o que de qualquer forma lhes será recusado e amar o que será inevitável (Bourdieu 1977: 77).

Como resultado, aqueles que não tem acesso às posições mais bem pagas da elite podem, por exemplo, celebrar que seu trabalho dá a oportunidade de desenvolver uma atividade socialmente gratificante. Ou, como observamos nas análises acima, aqueles provenientes das faculdades de nível inferior podem valorizar mais as configurações que se adequam ao seu estilo de vida, fazendo da necessidade uma virtude.

Enquanto traçamos caracterizações bastante fortes dos indivíduos nas descrições abaixo, nós também 
reconhecemos que não é determinante que alguns indivíduos sejam capazes de converter seu capital (Bourdieu, 1986). O que significa que o nível de suas faculdades, por exemplo, nem sempre dita a trajetória de suas carreiras. Além disso, como os entrevistados dessa pesquisa continuam construindo suas carreiras, podem acumular uma maior variedade de capital, que pode permitir esse processo.

Tais conversões são difíceis, mas é importante notar que nossa abordagem incorpora essas possibilidades. Como um todo, a análise fornece uma maneira de juntar as partes que constituem a profissão jurídica de modo estratificado. As hierarquias sociais dentro das profissões jurídicas, como vemos, produzem e reproduzem diferentes objetivos, expectativas, recompensas e satisfações.

\subsection{As elites: aguardando o tempo}

Brian $^{26}$ vem de uma faculdade de elite e de uma família bem relacionada do Sul dos Estados Unidos e trabalha numa grande banca em Chicago. Está na via rápida para adquirir mais credenciais, de acordo com o seu comentário que: "eu não me considero um advogado (...) frequentar a faculdade de direito foi para mim apenas uma forma de ter um bom diploma”. Presta pouca atenção para o que poderia levá-lo a se tornar sócio, porque não tem nenhuma intenção de permanecer no escritório, vendo este como um período de teste. Não tem pressa porque aspira trabalhar no serviço público, na cidade onde mora sua família. Sabe que tem muitas opções e não se limita apenas porque tem um diploma em direito. Seu comportamento sugere que não está satisfeito com sua posição no trabalho porque tem confiança que está numa trajetória de poder que pode, ou não, envolver o direito.

Jennifer atua numa empresa em São Francisco. Seu pai também trabalhava num escritório de advocacia proeminente. Ela frequentou uma faculdade de elite, ingressou numa empresa para trabalhar com contencioso e deixou a posição quando a economia estava em baixa. Usando um headhunter, mudou para outra empresa líder, mas queixa-se de falta de orienta-

26 Todos são pseudônimos, para proteger o anonimato dos entrevistados. ção, falta de interesse, em uma organização que cita como voltada a "faturar horas para ganhar dinheiro". Há sócias mulheres, mas os sócios são basicamente homens. Não está pensando em mudar imediatamente, mas não está feliz com a situação.

Os graduados nas dez melhores faculdades são esmagadoramente filhos dos favorecidos (ver Tabela 2). Frequentaram a faculdade de direito por razões elitistas, como desafio intelectual ou para buscar uma carreira satisfatória ${ }^{27}$.

Ao mesmo tempo, também tendem a considerar opções lucrativas e de prestígio alternativas, como a carreira em bancos de investimento. Suas possibilidades de escolha no campo jurídico são abundantes, o que se reflete no número de ofertas de trabalho que recebem no setor privado; poucos buscaram posições no setor público.

Uma vez que ingressam no mercado de trabalho, são levados para as quatro maiores áreas, para os escritórios de advocacia empresarial (mais de 100 advogados) e (comparados com a amostra como um todo) para bancas de assistência judiciária ${ }^{28}$, o que não exclui, necessariamente, outras opções no setor privado. Eles têm uma carreira veloz e estão nela por escolha, o que reflete sua avaliação sobre prestígio e mobilidade em relação ao estilo de vida possível no setor onde escolheram atuar.

Os bacharéis provenientes das melhores faculdades têm vantagens, mas os dados sugerem que não ne-

27 Os entrevistados foram convidados a classificar oito objetivos quando tomaram a decisão de ir para a faculdade de direito. Esses foram reduzidos em três fatores baseados em análise fatorial. 0 primeiro, "solidariedade", é composto por itens que refletem o desejo de ajudar outras pessoas; "prestígio" é formado por itens que refletem desafio intelectual e desejo de adiar a entrada no mercado de trabalho; e "carreirismo" reflete uma preocupação com segurança financeira e construção de habilidades.

28 Nota das tradutoras: o termo original era "public interest law fir$m s$ " que se diferenciam de escritórios privados de advocacia, pois a sua missão principal é fornecer assistência judiciária a pessoas que não podem arcar com os custos, bem como causas que são tidas como relevantes socialmente. Os clientes podem ser escoIhidos a partir da necessidade ou em razão das causas que mobilizam, ao invés da sua capacidade de pagar pelos serviços prestados. Dessa forma, os profissionais têm uma remuneração inferior que aquela dos escritórios privados. 
Tabela 8. Estatísticas Chave para Medidas do Processo de Classificação dos Advogados

\begin{tabular}{|c|c|c|c|c|c|c|}
\hline & Top 10 & Top $11-20$ & Top $21-40$ & Top $41-100$ & $3^{x}$ Categoria & $4^{x}$ Categoria \\
\hline \multicolumn{7}{|l|}{ Avaliação da razão que foi para a faculdade de direito (percentual médio) } \\
\hline Solidariedade & 51 & 50 & 48 & 50 & 52 & 49 \\
\hline Cameirista & 47 & $46^{* *}$ & 49 & 51 & 52 & 51 \\
\hline Elite & $54^{*}$ & 52 & 51 & 49 & 48 & 49 \\
\hline $\begin{array}{l}\text { Mais provável (p< }<0.05 \text { que outros grupos a responder que tem considerado } \\
\text { uma carreira em... }\end{array}$ & Banco de investimento & Organização comunitária & - & - & Con & Comecando um negócio \\
\hline Recebeu duas ou mais ofertas no setor privado & $76 \%+4$ & $62 \%+4+$ & $54 \%$ & $45 \%+*+$ & $44 \%^{*}$ & $40 \%$ \\
\hline \multicolumn{4}{|l|}{ Avaliação do porquê escolheu determinado setor (percentual médio) } & $1990^{*+*+*}$ & $19 \% *$ & $17 \%$ \\
\hline Estilo de vida e interesse & $40^{+*+4}$ & $46^{*}$ & 48 & $54^{+\infty+4}$ & 52 & 50 \\
\hline Prestigio e mobilidade & $57^{* *}$ & 52 & 52 & 51 & $46^{* *}$ & $46^{*}$ \\
\hline Salário & 52 & 53 & 51 & $48^{*}$ & 49 & 51 \\
\hline $\begin{array}{l}\text { Avaliação das oportumidades de progresso } \\
\text { (escala }=1-7) \text { (média) }\end{array}$ & 4.59 & 4.81 & 4.78 & 4.73 & $4.42^{*+4 *}$ & 4.62 \\
\hline Networking com sócios ou advogados sêniores" & $54 \% \%^{*}$ & $60 \%$ & $67 \%$ & $65 \%$ & $63 \%$ & $59 \%$ \\
\hline Salário (média) & $\$ 122,147^{4+4 *}$ & $\$ 104,213^{44-4}$ & $\$ 91,256^{4+4 *}$ & $\$ 77,222^{*+* *}$ & $\$ 67,757^{*+4 *}$ & $\$ 69,365^{4+4 *}$ \\
\hline Horas trabalhadas por semana (média) & $51^{* *}$ & 49 & 49 & 48 & 48 & 49 \\
\hline \multicolumn{7}{|l|}{ Avaliação da satisfação com (percentual médio) } \\
\hline Contexto de trabalho & $43^{*+*}$ & $43^{*+4 *}$ & 49 & $52^{* *}$ & 53 & $53^{* *}$ \\
\hline Substância do trabalho & $46^{*}$ & 48 & 51 & 51 & 50 & 52 \\
\hline Indice social & 49 & 50 & $46^{* *}$ & 51 & 47 & $54^{*}$ \\
\hline Faixa de poder & $63^{4+4-4}$ & $61^{*+4 *}$ & $56^{4+4 *}$ & $48^{* *}$ & $42^{4+4 *}$ & $40^{4+4 *}$ \\
\hline Porcentagem relatando que ainda não mudaram de emprego & $67 \%^{*}$ & $68 \%$ & $65 \%$ & $64 \%$ & $61 \%$ & $64 \%$ \\
\hline Porcentagem vivendo em grandes áreas metropolitanas & $77 \%$ & $5988^{*+* *}$ & $48 \%+4 *$ & $32 \%$ & $35 \% *$ & $19 \%+4$ \\
\hline$n$ total de niveis & 332 & 430 & 539 & 1176 & 619 & 536 \\
\hline
\end{tabular}

Nota: Testes de significância comparam categorias das faculdades de direito selecionadas com os entrevistados de todas as outras categorias. Valores são percentagens, exceto quando indicado de outra forma. O número de casos perdidos varia de acordo com as variáveis.

aUtilizamos o subconjunto de casos da pesquisa por correspondência para esta tabulação cruzada. ${ }^{*} p<.0 .05,{ }^{* *} p<.0 .01,{ }^{* * *} p<.0 .001$ (bicaudal).

cessariamente apreciam tais vantagens. Enquanto são significativamente menos propensos a mudar de emprego, tendem a expressar planos de deixar as posições que ocupam em um futuro próximo. Quando comparados com os bacharéis de todas as outras faculdades, que também estão trabalhando em escritórios grandes, verificamos que tendem a expressar intenção de deixar seus empregos.

As práticas profissionais estão configuradas de modo que lhes demanda trabalhar por muitas horas, o que se traduz, para eles, como menor satisfação com seus trabalhos. Esse senso de ambivalência com seus cargos é semelhante com sua ambivalência em relação à escolha de carreira, reportando os menores níveis de satisfação com a decisão de tornarem-se juristas. Tal ambivalência relativa também é percebida em seu envolvimento no trabalho, pois os estudantes de faculdades de elite reportam menos contato com os sócios, sugerindo que não investem em acumular capital social, se isso demanda mais esforço.

A combinação entre ocupar posições privilegiadas e demonstrar satisfação relativamente menor sugere que aqueles que vem das melhores faculdades tomam por certo que terão sucesso mas ao mesmo tempo, também se arrependem em relação às outras opções que poderiam ter buscado, quando as percebem como ao menos tão satisfatórias quanto às que ocupam. Esses bacharéis da elite estão prontos e esperam mover-se, se e quando, algo melhor surja, mas a sua falta de mobilidade relativa sugere que o descontentamento visto através dos planos de mudança, não necessariamente leva a movimentos reais no curto prazo. Nesse estágio de suas carreiras, ainda estão lidando com os planos moldados para eles por terem frequentado as faculdades de direito de elite.

Ainda, a trajetória da elite não é de toda a porção. Como a história de Jennifer sugere, mesmo entre a elite, as mulheres e as minorias continuam a enfrentar obstáculos.

Enquanto as credenciais de elite conferem e reafirmam uma trajetória de sucesso para a maior parte dos bacharéis, tais credenciais não afastam totalmente as estruturas de desigualdade da profissão bem estabelecidas. Esses obstáculos não são o foco desse artigo, mas é claro que as profissões jurídicas estão estruturadas de modo que o domínio do jogo de sucesso venha de modo mais simples para os homens brancos. 


\subsection{Os "quase" elite - sempre em segundo lugar (Top 11-20)}

Kate foi chamada a participar de vinte e uma seleções de emprego, quando já estava no mercado de trabalho e confiantemente relatou que as reduziu a três que de fato aguentaria atuar. Decidiu trabalhar em uma pequena filial de uma grande empresa, pois dá uma sensação familiar. E, como Brian, escolheu uma grande empresa por que queria manter as opções abertas. Trabalha duro, em torno de 2.800 horas, e já compreendeu que não foi tão agressiva quanto deveria ter sido no seu primeiro ano. Ela também está ganhando experiência por meio de extensivo trabalho pro bono, que conta em suas horas faturáveis. Sabe que se quiser, pode tornar-se sócia do escritório, mas pensa em mudar para uma atividade no governo, se as horas de trabalho atrapalharem sua vida pessoal. Seus pais não são profissionais do meio jurídico $e$ seu acesso não é facilitado. Diz que "está nas minhas mãos aprender a administrar meu tempo e dizer não".

Em quase todos os aspectos, os bacharéis de faculdades ranqueadas entre as top 11-20 são quase idênticos aos estudantes da elite. A experiência desses entrevistados é claramente privilegiada, reportando níveis significativamente altos de prestígio profissional por parte de seus pais, em comparação com os entrevistados das outras faculdades. Também investem pesadamente no setor privado.

E, enquanto são privilegiados, se comparados com a média dos demais entrevistados, a eles não são dadas as mesmas oportunidades que o grupo de elite. Isso se reflete, comparativamente, em menos ofertas de emprego e menor probabilidade de atuação em grandes bancas, salários um tanto menores e mais horas trabalhadas, além de mais atenção ao salário como um fator decisivo para a escolha de uma posição. Muitos deles também trabalham duro para conquistar suas funções se comparados àqueles das faculdades de elite, sugerindo que as notas importam mais quando se baixa a hierarquia da escola.

Não surpreende que aqueles que trabalharam mais pesadamente para conquistar suas posições não sejam tão descuidados. Esses bacharéis mencionam altas taxas de estabilidade nos empregos anteriores e não tendem, como outros, a expressar intenções de deixar seus cargos dentro de dois anos.

Enquanto expressam a mesma insatisfação relativa com aspectos das grandes bancas como aqueles formandos nas faculdades de elite, a maioria deles está satisfeito com sua decisão de tornarem-se juristas (embora estejam menos satisfeitos que os bacharéis de outras camadas). 0 grande comprometimento com seus trabalhos também se reflete no fato de que grande parte desses graduados estabelece redes com parceiros, refletindo um esforço na construção de relações em seus locais de trabalho; também percebemos esse comprometimento na sua avaliação quanto às oportunidades de progresso, que são relativamente altas.

Em suma, enquanto este grupo está mais próximo a elite em termos de onde trabalham, tendem a ser mais agradecidos pelas posições que encontraram, compartilhando algumas das características daqueles provenientes de faculdades pior ranqueadas.

\subsection{Entre as elites e o meio (Top 21-40)}

O pai de Mike desempenha uma função administrativa cujo prestígio é relativamente baixo. Mike formou-se em uma das principais universidades estaduais de direito e encontrou emprego na área do direito do trabalho, em um grande escritório de advocacia. É casado, gosta do seu trabalho e mudaria somente se um dos principais sócios do escritório mudasse. Seu comportamento é em alguma medida menos confiante, que aquele dos bacharéis provenientes das melhores faculdades. Como diz "apenas foco no dia a dia, fazendo meu trabalho, tentando fazer o meIhor que posso e, muito francamente, esperando que as coisas permaneçam no lugar". Enquanto Brian e Kate estavam excedendo suas faturas, Mike diz que "temos um mínimo de 2.000 horas. Eu pessoalmente trabalho muito mais que isso". Acredita que está aprendendo importantes habilidades, que está no caminho certo para tornar-se sócio e tem pouco a dizer em tom de reclamação.

Os profissionais provenientes das faculdades ranqueadas entre 21-40 têm experiências semelhantes àquelas dos grupos descritos acima. Mas as linhas de demarcação ficam muito mais claras nesse nível.

Em quase todos os critérios além da classe social, gradu- 
ados nesse grupo estão abaixo daqueles localizados entre as 20 melhores faculdades: recebem menos ofertas de trabalho, uma proporção menor deles trabalha em grandes bancas e ganham menos. Também expressam sentimentos que divergem daqueles da elite: tendem menos a dizer que cursaram direito para ajudar as pessoas. São mais gratos às oportunidades que tiveram.

Quando comparados aos bacharéis das faculdades de elite, são mais comprometidos com seus empregadores, fazem mais redes e são mais satisfeitos com a decisão de tornarem-se juristas.

Tendem a expressar uma preferência maior, embora estejam abaixo da média da amostra, quanto à trabalhar em posições com cujo estilo de vida se identificam, se comparadas aquele encontrado nas grandes bancas corporativas. Valorizar o estilo de vida - vemos aqui e dentro das camadas inferiores da pesquisa - não se trata apenas de uma preferência. Mas como uma justificativa para aceitar o trabalho menos prestigioso, disponível para eles. Um bacharel que não pode acessar as posições de elite tende, portanto, a fundamentar suas escolhas a partir do estilo de vida para aceitar este fato.

\subsection{Felicidade no topo do meio (41 a 100)}

Graduado em uma pequena faculdade de direito, Robert, cujos pais não tinham ensino superior, encontrou emprego em uma empresa relativamente grande de seguros, onde, segundo ele, o treinamento era "inacreditável”. Trabalhar em uma empresa, portanto, é mais que uma referência para ele e, enquanto também está feliz com a experiência que adquire, com a supervisão e com as relações que estabelece no cargo, inveja aqueles que atuam em funções de prestígio. Também em contraste com os graduados oriundos de estratos superiores, diz que a parte mais difícil de sua atividade são as demandas quanto ao faturamento. São uma fonte de estresse constante e um objetivo muito duro para dar conta. Seus planos para o futuro são mudar-se para o contencioso comercial, pois espera encontrar um cargo que atue como advogado. Reconhece que foi feliz até hoje e diz que está em suas mãos construir a carreira que deseja, pois não pode contar com sucesso profissional inerente.

Os profissionais oriundos das faculdades ranqueadas entre 41-100 vêm de experiências menos privilegiadas que aqueles das melhores classificadas e percebem a faculdade de direito como parte de um projeto de ascensão.

Quando perguntados sobre porque decidiram cursar direito, por exemplo, fornecem razões carreiristas. Suas perspectivas são limitadas, dispondo de menos opções que o setor privado e, apenas dez por cento deles, conseguem uma vaga nas maiores bancas (aquelas que contam com pelo menos 100 advogados). Esses entrevistados dão classificações mais altas para o peso do estilo de vida na sua escolha de carreira, como é esperado, mas também enfatizam a importância do prestígio para as suas escolhas.

Uma vez que o direito lhes dá ascensão profissional, esse grupo investe fortemente nas suas trajetórias profissionais. Grande parte deles espera continuar em seus empregos dentro dos próximos dois anos ou mais. Sabem que a faculdade de direito fez diferença nas suas perspectivas de carreira e mais de um terço deles está extremamente satisfeito com a decisão de formar-se em direito. Não tomam como certo que terão uma carreira de sucesso, trabalham muitas horas e dão duro, também na construção de redes. Tentam assiduamente aprender as regras de progressão, ao invés de confiarem na percepção para o jogo.

As recompensas para esses investimentos são bastante tangíveis: enquanto seus salários são mais baixos que a média, eles são mais altos que os das camadas mais baixas. Entretanto, as horas de trabalho deles não são menores que as da média. Além disso, sua satisfação com o trabalho é maior que a média, mas a satisfação com a trajetória de poder é mais baixa, ao mesmo tempo que estão mais satisfeitos com a trajetória de poder do que aqueles abaixo deles. Sabem que atingiram mobilidade ascendente e estão satisfeitos, mesmo que não tenham as mesmas perspectivas de carreira que aqueles que começam no topo.

\subsection{A terceira camada: a batalha por ascensão}

Graduada em uma escola um pouco melhor ranqueada que as da terceira camada, a experiência de Mary é esclarecedora. Estudante do curso noturno, proveniente de uma família de operários, sem notas 
altas, encontrou trabalho convertendo seu emprego de meio período para uma posição de tempo integral em uma empresa de coleta. Continua a enfrentar dificuldades e procura por várias oportunidades dentro e fora do campo do direito. Rejeita a ideia de tornar-se sócia de um escritório referindo-se ao estilo de vida: trabalhar setenta e oito horas. Diz que não pensa em voltar a estudar para obter mais competências, então sua carreira não sai do estágio que está. Não gosta do trabalho que faz e diz que o mesmo se aplica aos seus colegas de faculdade: "estamos todos no mesmo barco atualmente, nenhum de nós quer fazer o que está fazendo".

Heather cursou direito em uma faculdade situada no terceiro nível do ranking no período noturno e aceitou um cobiçado emprego no governo federal. Explica que, enquanto o nome da faculdade de direito que cursou não foi fundamental para encontrar a posição, usou o ranking para provar que tinha a formação adequada e a experiência necessária para o trabalho. Diz que sempre foi uma estudante mediana e que seus pais provêm da classe trabalhadora, mas está investindo fortemente no futuro, trabalhando de dez a onze horas por dia e muitos finais de semana. Sua perspectiva é otimista, pois vê muitas oportunidades para progredir, por isso nunca diz nunca. Por enquanto está solteira, mas acredita que mesmo com uma família, seu local de trabalho permite balancear entre vida pessoal e profissional.

Em termos de histórico socioeconômico, a faculdade de direito para a terceira camada aparece como representando ascensão: a maior parte desses bacharéis relata que cursou direito por questões carreiristas, mas também cursaram direito para ajudar os outros, talvez por que lembrem de onde vêm.

Sua experiência no mercado de trabalho é bastante semelhante àquela dos localizados na camada acima, mas tendem a trabalhar predominantemente sozinhos ou em pequenos escritórios.

Muitos deles fundamentam a escolha apontando o estilo de vida, como o comentário de Mary sobre as horas trabalhadas, de modo a justificar como escolha o fato de não trabalhar em posições que não estão disponíveis para eles.
As experiências desse grupo também sugerem uma luta contínua. Eles têm menos segurança do que outros entrevistados, mais impermanência nos empregos passados e aspiram mais mobilidade num futuro próximo.

Essa luta também se evidencia nas avaliações quanto às oportunidades de crescimento, que são as mais baixas de todos os grupos. O que se reflete em uma estratégia muito diferente da adotada pelos estudantes de elite, que dão como certo que irão começar e terminar suas carreiras no topo. Os bacharéis da terceira camada se empenham muito para construir suas carreiras e trabalham o mesmo número de horas do que aqueles situados nas camadas superiores.

Os benefícios não tendem a vir tão facilmente para eles, que ganham menos e expressam níveis mais baixos de satisfação com a carreira. Mesmo assim, as profissões jurídicas continuam a oferecer-lhes alguma satisfação, particularmente em relação às tarefas do trabalho, que avaliam melhor do que a média dos entrevistados. E no caso daqueles que atuam em grandes bancas o comprometimento é claro, pois não expressam intenção de deixar seu emprego.

Assim, embora trabalhem muito e ganhem pouco, estão cientes de sua posição de ascensão, com mais de um terço alegando estar extremamente satisfeito com a decisão de tornar-se advogado.

\subsection{A quarta camada: os mais satisfeitos?}

Anna formou-se em uma escola de direito mal avaliada, enquanto trabalhava em tempo parcial. Para ela o direito é um caminho para uma trajetória ascendente: "minha mãe era empregada doméstica... eu sabia que eu não queria fazer aquilo". Enquanto estava na faculdade de direito, um professor arranjou-lhe um estágio com um juiz e, depois da formatura, começou a trabalhar como assessora em um juizado bastante atribulado. Quando questionada se trabalharia no setor privado, aponta razões pessoais, explicando que são muitas horas de dedicação. E diz que sabia que não ia querer fazer isso. Sobressaindo-se através de trabalho duro, teve sucesso na aquisição de competências e hoje trabalha como procuradora-geral local, ganhando experiência jurídica na área contenciosa, que manterá sua carreira em progressão. É um exemplo excepcional da quarta camada, mas instru- 
tivo quanto aos passos que precisou dar para traçar uma carreira respeitável.

Susan graduou-se entre os melhores da turma e trabalha num escritório composto por 100 advogados. Se inicialmente pensou que queria trabalhar em uma grande banca, disse que ao perceber a quantidade de horas que precisam ser trabalhadas nesses escritórios, não queria aquilo. Em contraste com os bacharéis provenientes das elites, Susan diz que escolheu a configuração de trabalho por que 'o direito não é minha vida' e mesmo que as grandes bancas tenham uma reputação incrível, queria um escritório familiar. Tem se saído bem, o que é evidenciado por sua frase 'não consigo expressar o quão feliz estou'. $\mathrm{E}$, novamente em contraste com as expressões de insatisfação e intenção de mobilidade demonstradas pelos bacharéis das elites, quando perguntada se ela continuará lá nos próximos cinco anos, responde: "eu serei sócia, vou me casar e então quero ter dois filhos. Terei sustentado na Corte de Apelação Estadual e terei muitos outros clientes. Terei pelo menos quatro vezes mais experiência. Isso é o que sei neste momento".

Os bacharéis das faculdades da quarta camada vêm de configurações menos favorecidas; seus pais têm graus de instrução mais baixos e desempenham as funções profissionais de menor prestígio na amostra.

Tendem mais que os outros a começarem seus próprios negócios como estratégia de carreira, em dramático contraste com os estudantes das elites. Além disso, as entrevistas novamente revelam a influência de uma escolha justificada pelo estilo de vida, dizendo que rejeitam as longas horas de trabalho, associadas com as grandes bancas.

Ao mesmo tempo, suas experiências no mercado de trabalho sugerem que estão ocupando uma necessidade de mercado particular e enquanto muitos deles receberam mais de duas ofertas, suas chances de receberem pelo menos uma oferta de emprego não é diferente da média.

As características do trabalho desempenhado por eles estão em forte contraste com aquelas dos bacharéis das elites: quase metade dos provenientes da quarta camada trabalham em pequenas bancas ou sozinhos; são os que menos expressam que prestígio e mobilidade são elementos importantes na escolha pela prática no setor privado. Possivelmente isso reflete as escolhas de alguma forma limitadas, que encontraram no mercado de trabalho.

Os bacharéis da quarta camada trabalham duro. Trabalham tanto quanto os outros recém-graduados (exceto as elites) mas recebem menos. Já experimentaram alguma instabilidade, pois em torno de 35\% deles mudou de emprego ao menos uma vez na vida. Entretanto seu comprometimento é claro: em torno de $60 \%$ deseja ficar no emprego atual por mais de dois anos, demonstrando que percebem oportunidades para crescimento onde estão.

Considerando que permaneçam onde estão, apontam níveis altos de satisfação com o formato do trabalho, a essência do trabalho e o índice social, novamente apontando fazer das necessidades virtudes. Uma porcentagem maior desses juristas, se comparados com qualquer outro grupo, assevera estar extremamente satisfeita com a decisão de tornarem-se advogados.

Assim, embora as circunstâncias objetivas sejam piores, se comparados com os provenientes das camadas superiores, esses bacharéis estão mais cientes do impulso que o diploma deu às suas carreiras. Acreditam que são sortudos e faz pouco sentido desejar conquistas profissionais inatingíveis para eles. Também estão mais ou menos satisfeitos com a posição que estão e planejam nela continuar, especialmente se podem mudar para uma grande banca e batalhar por progressão.

\subsection{Juntando e combinando carreiras e pessoas: classe social na escolha} profissional

Nesse estágio inicial das carreiras dos bacharéis, já fica claro como os sentimentos de satisfação e insatisfação estão relacionados e legitimam as estruturas hierárquicas das profissões jurídicas.

Aqueles que podem obter as posições mais prestigiosas e lucrativas nas grandes bancas advocatícias e empresas fazem isso. Trabalham muitas horas e in- 
ternalizam uma relativa insatisfação que os encoraja a moverem-se. A felicidade relativa com o trabalho e com as funções desempenhadas nas grandes bancas empresariais ajuda aqueles das faculdades dos níveis mais baixos, que tipicamente vêm de formações desvantajosas a se sentirem orgulhosos de suas escolhas, ou encontrarem o que Lamont (2000) chama de dignidade.

Como McGill (2003) mostrou em seu estudo sobre a cultura das faculdades de direito, as faculdades piores classificadas encorajam os alunos a considerarem as carreiras disponíveis para eles como valorosas profissionalmente, enfatizam valores como o serviço aos clientes e o próprio acesso às carreiras jurídicas.

Ao mesmo tempo, a atribuição de alguma ternura ao trabalho desempenhado nas grandes bancas se dá para os que têm a oportunidade de atuar nelas dentro dessa estrutura de elite. $E$ alguns dos alunos das faculdades de elite desistem dessa trajetória no início de suas carreiras. As dificuldades do trabalho nas grandes bancas por eles apontadas, surgem como elementos necessários para o processo de aceitação do acesso desigual aos trabalhos jurídicos bem remunerados e prestigiosos.

A relativa falta de satisfação das elites, nós notamos, também tem um papel importante na dinâmica interna das grandes bancas de advocacia. Fica claro que a economia dos grandes escritórios depende do fato de apenas poucos associados tornarem-se sócios (Galanter \& Palay 1991). As longas horas associadas ao trabalho, por outro lado, são essenciais para os lucros dos sócios. Muitos deles diminuíram tais lucros. A estrutura básica é a base da hipótese de Galanter e Palay sobre a competição entre os advogados.

É difícil de administrar uma competição. Entretanto, quando há muitos concorrentes e os critérios para a vitória não são precisos fica mais fácil fazê-lo. Nossa hipótese é que insatisfação relativa encoraja o atrito e torna o processo de triagem mais fácil de ser administrado pelos diretores dos escritórios.

Embora não exista pesquisa detalhada sobre a forma como se dão as decisões de tornar ou não os advogados sócios, é certo que produzir decisões claras, se todos os associados buscarem competir por uma posição, será mais difícil. Talvez seja relativamente fácil usar avaliações para determinar o sucesso profissional entre os associados, mas é difícil decidir quem se sobressai para merecer tornar-se sócio. 0 estilo de vida árduo das grandes bancas, que impele o alto grau de atrito, torna essas decisões de alguma forma mais fáceis.

Os padrões de mobilidade levantaram algumas preocupações, entretanto, quando examinados por raça e gênero. Nossos dados indicam que as mulheres tendem mais que os homens a planejar deixar seus empregos dentro de um ano, assim como as minorias também tendem a expressar mais essa intenção.

Os escritórios estão sob grande pressão para contratar e manter mais mulheres e minorias (Wilkins, 2004; McDonough, 2005), mas o sistema de alto atrito reafirma os padrões das grandes bancas empresariais como ainda sendo instituições brancas e masculinas.

Uma minoria de mulheres na amostra da pesquisa participou de uma captação em escritórios corporativos desenhada justamente para encorajar as minorias a considerarem seguir carreira em tais escritórios. Sentindo-se deslocadas e estranhas durante o evento, que contou com discussões sobre golfe e outros assuntos semelhantes, uma das entrevistadas apreendeu uma mensagem diferente e buscou por uma carreira na esfera pública.

Um homem negro que respondeu a pesquisa, de histórico familiar de classe trabalhadora, mas também com outras credenciais das elites, disse que as bancas empresariais para as quais ele trabalhou desejavam que ele fosse bem sucedido, mas que se sentia como um outsider, fingindo se dar bem em um ambiente no qual não se encaixa.

Essas expressões são relativamente comuns entre os entrevistados. Minorias e mulheres que escolhem deixar de lado a carreira em grandes bancas podem acreditar que se trata de uma escolha própria, possivelmente por razões pessoais, mas o impacto cumulativo e sentimentos como os descritos acima sugerem que a dinâmica institucional das bancas empresariais também influenciam no processo. 


\section{Conclusão}

As implicações do sistema de estratificação documentado nesse paper e em outros (Heinz et al. 2005; Hagan, Huxter and Parker, 1988; Auerbach, 1976) são significativas. Sabemos, por exemplo, a partir do trabalho inovador sobre os advogados de Chicago (Heinz et al. 1995, 2005), que a profissão jurídica é dividida em dois hemisférios, com uma esfera servindo às corporações e outra servindo às pessoas físicas. É claro, a partir dos dados do DGD, que essa segmentação dos juristas entre as duas esferas começa muito cedo em suas carreiras e que isso está relacionado aos padrões de estratificação.

De acordo com os dados da Figura 3, os bacharéis provenientes das dez melhores faculdades de direito afirmam, na média, que gastam $69 \%$ do seu tempo servindo empresas e $35 \%$ do tempo representando pessoas físicas ou pequenas empresas ${ }^{29}$. Os padrões quase se invertem quando descemos na hierarquia das faculdades de direito. Em média, os graduados da quarta camada, devotam $28 \%$ do seu tempo representando clientes corporativos e $57 \%$ do tempo deles com pessoas físicas ou pequenos negócios.

A correlação direta entre a classificação da faculdade de direito e o tipo de cliente, bem como o padrão escalonado dessa correlação, demonstra que o sistema de estratificação nas profissões jurídicas é ainda mais complexo do que a tese dos dois hemisférios sugere.

A passagem dos bacharéis das faculdades de elite para a esfera corporativa tem há muito levantado questões sobre as formas como os recursos das profissões jurídicas são investidos (conforme Abel, 1989; Hadfield, 2000), e os padrões que apresentamos nessa pesquisa demandam reflexões mais aprofundadas sobre as implicações da estratificação no campo jurídico (Bourdieu, 1987).

Quando os bacharéis das faculdades das camadas mais baixas aceitam seus lugares na hierarquia da profissão e também exaltam as virtudes de suas escolhas, ao justificá-las a partir dos benefícios vislumbrados no estilo de vida que levam, encontramos uma convergência contínua entre os bacharéis da elite e os clientes corporativos, que é reproduzida através das preferências de carreira.

Como pesquisas recentes indicam, é precisamente essa convergência que continua a proporcionar aos escritórios de advocacia seu próprio status, e subscreve sua habilidade de conservar e lucrar com clientes corporativos (Uzzi; Lancaster, 2004). E essa hierarquia é legitimada por meio de aspirações individuais de carreiras, que garantem que qualquer mudança seria difícil de ser efetivada e que as faculdades de elite continuam a tirar seus alunos de origens sociais predominantemente privilegiadas e continuarão a colocar seus alunos em grandes empresas urbanas, gerando riqueza para clientes corporativos.

Esse é um paradoxo que alguns dos novos bacharéis de elite devem estar enfrentando, quando olham para fora das oportunidades dentro das grandes bancas empresariais. As implicações das transformações, entretanto, permanecem desconhecidas: enquanto podem resultar na mudança dos escritórios, podem ainda funcionar para diferenciar os estudantes de elite, com impactos que até ampliam a influência dos escritórios e das faculdades de direito para além do campo jurídico. A satisfação dos bacharéis, como resultado, fornece um sinal inicial sobre como os valores simbólicos do direito devem ser refeitos ou reproduzidos nas próximas décadas. 
Figura 3. Porcentagem média representando os tipos de cliente por categoria da faculdade de direito.

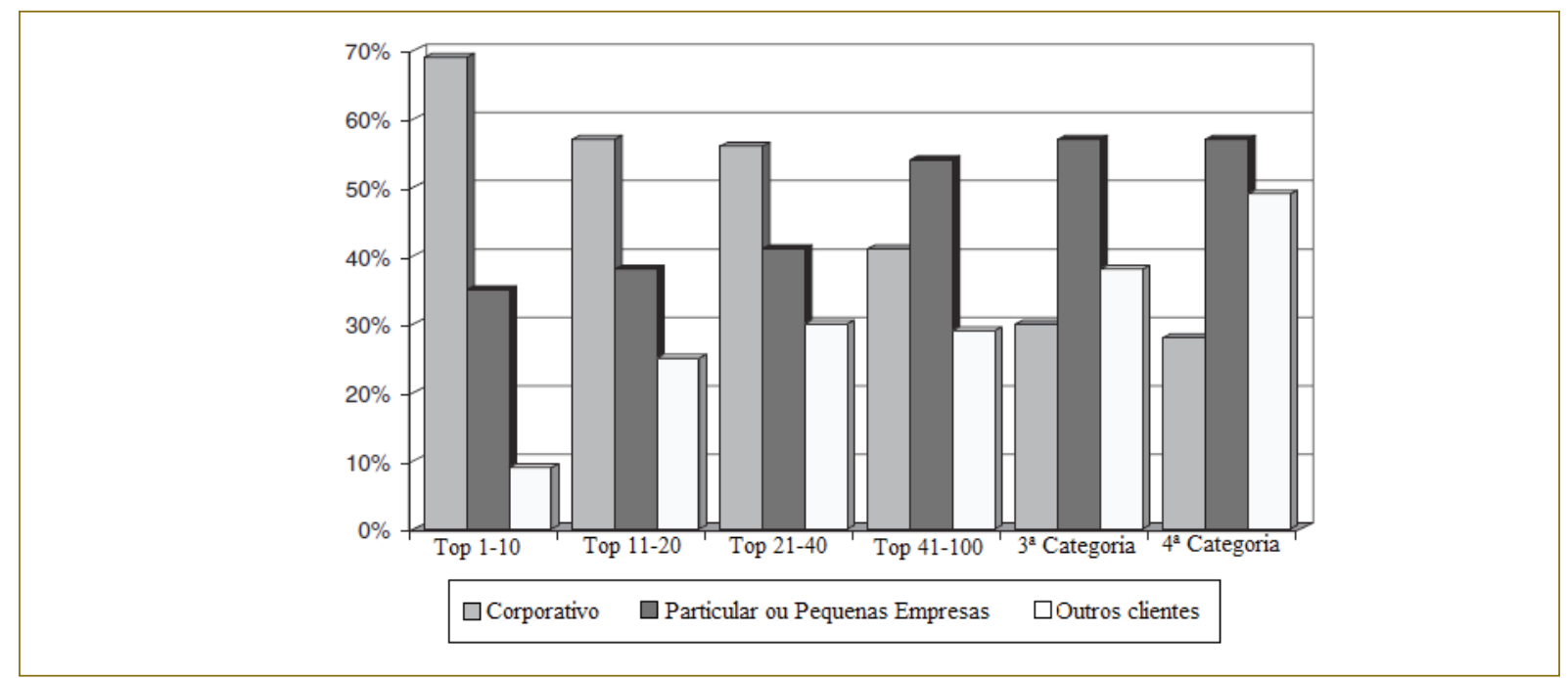

\section{Apêndice A. Regressão logística Multinominal das Intenções de Deixar o Empregador (comparada àqueles que pretendem fazê-lo em 5 anos ou mais) $(n=1.467)$}

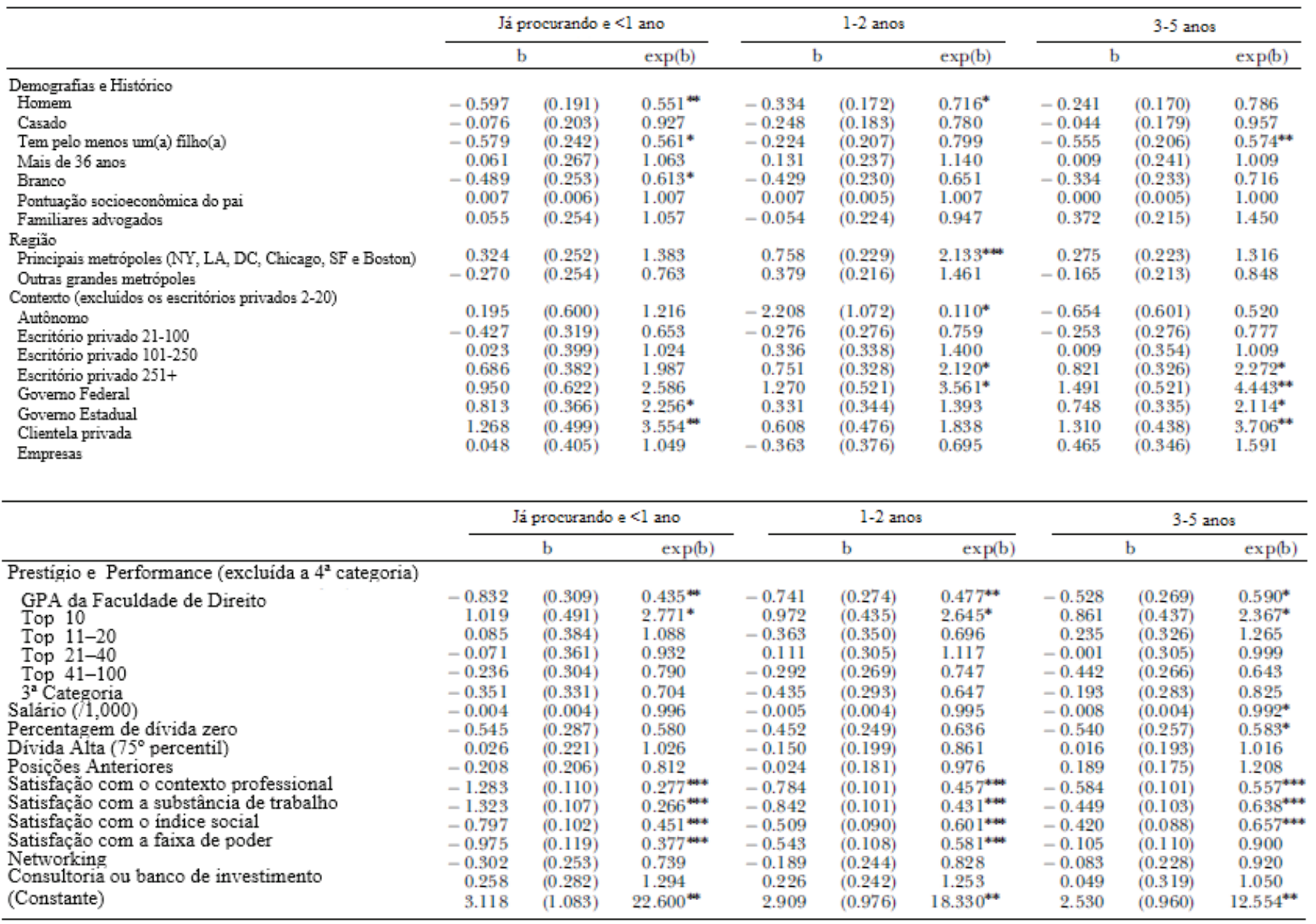

Nota: Os números em parênteses são os erros padrão.

${ }^{a}$ Apêndice A exibe resultados de múltiplos dados imputados. Favor consultar o texto para discussão dos procedimentos sobre dados ausentes.

$" p<.05,{ }^{* *} p<.01,{ }^{* *} p<.001$ (bicaudal). 


\section{Apêndice B}

Também testamos interações para explorar se a própria categoria da faculdade de direito estrutura os vários fatores que afetam a satisfação no trabalho e as intenções de mobilidade.

Isto significou dividir a amostra em seis subamostras baseadas na categoria da faculdade de direito, e construir todos os modelos apresentados no artigo dentro de cada uma dessas subamostras. Em segui$\mathrm{da}$, comparamos os coeficientes b produzidos em cada modelo através das categorias da faculdade de direito (usando os testes $Z$ apropriados) para testar interações significativas.

Embora os resultados sejam complexos, eles continuam complementando as descobertas apresentadas no artigo, e relatamos aqui alguns dos achados mais salientes e significativos ( $p<.05$ ou mais para todos os efeitos relatados abaixo).

Modelando as intenções dos entrevistados de deixarem seus empregadores, descobrimos que os dez melhores graduados com dívida alta são mais propensos a pensarem em deixar seus empregos dentro de dois anos, em comparação aos graduados de quarta categoria. Nós também achamos que a satisfação com a essência do trabalho e o índice social reduz as intenções de mobilidade de trabalho para os graduados das dez melhores faculdades em comparação com todos os outros graduados em direito.

Nos modelos de satisfação profissional encontramos um efeito significativo para gênero: os homens das dez melhores faculdades relatam maiores níveis de satisfação do que as mulheres quando comparados com os graduados das 40 melhores faculdades e das de quarta categoria. Também encontramos que para os graduados das 40 melhores faculdades, ter tido uma posição melhor reduz significativamente a satisfação com a carreira quando comparado com os graduados de faculdades classificadas entre 100 ou abaixo.

Os modelos para os quatro tipos de satisfação no trabalho sugerem que o salário pode trabalhar de diferentes maneiras para os entrevistados de diferentes faculdades de direito: o salário aumenta significativamente a satisfação com ambiente de trabalho dos graduados de quarta categoria em comparação com os graduados das dez melhores faculdades, e aumenta a satisfação com a faixa de poder dos profissionais das faculdades de terceira categoria em comparação com os das top 10.

Os modelos também indicam que o status socioeconômico do pai é condicionado pelo ranking das faculdades de direito: para os dez melhores graduados, os aumentos no status socioeconômico do pai resultam em níveis significativamente mais altos de satisfação com o ambiente de trabalho em comparação com os graduados de todas as outras faculdades de direito (exceto aqueles da terceira categoria).

Os dados também sugerem que a idade interage de forma importante com a categoria da faculdade de direito. Os entrevistados que possuem mais de 36 anos e que frequentaram uma das 20 melhores faculdades de direito relatam níveis mais baixos de satisfação com o conteúdo do seu trabalho do que os graduados das faculdades de categoria inferior.

Nós também descobrimos que o GPA (Grade Point Average) da faculdade de direito aumenta significativamente a satisfação com o ambiente de trabalho para os graduados das 10 melhores faculdades em comparação com aqueles do top 40, top 100 e terceira categoria.

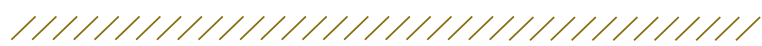




\section{Referências}

Abel, Richard L. (1989) American Lawyers. New York: Oxford University Press. Allison, Paul (2002) Missing Data. Thousand Oaks, Calif.: Sage.

American Bar Association (2005) Section on Legal Education. First Year Enrollment in ABA Approved Law Schools 1947-2004 (Percentage of Women) Available at: http://www.abanet.org/legaled/statistics/femstats.html (accessed April 24, 2005).

American Bar Association Young Lawyers Division (2000) ABA Young Lawyers Division Survey: Career Satisfaction. Chicago, IL. Available at: http://www. abanet.org.myaccess.library.utoronto.ca/yld/satisf action_800.doc (accessed April 24, 2005).

Adams, Edward A. (1994) Legal Career Exacts Steep Personal Price. New York Law Journal. Feb 7, 1994, at 1.

Auerbach, Jerold S. (1976) Unequal Justice: Lawyers and Social Change in Modern America. New York: Oxford University Press.

Carson, Clara (2004) The Lawyer Statistical Report: The U.S. Legal Profession in 2000. American Bar Foundation. Chicago, IL.

Boon, Andrew, Liz Duff \& Michael Shiner (2001) Career Paths and Choices in a Highly Differentiated Profession: The Position of Newly Qualified Solicitors. 64 Modern Law Review 563-594.

Bourdieu, Pierre (1977) Outline of a theory of practice. Cambridge: Cambridge University Press.

----. (1987). The Force of Law: Toward a Sociology of the Juridical Field. 38 Hastings Law Journal 805-853

----. (1996) The State Nobility: Elite Schools in the Field of Power. Oxford, England: Polity Press. -----. (1998) Practical Reason: On the Theory of Action. Cambridge: Polity Press.

----. (2003). Firing Back: Against the Tyranny of the Market. New York: New Press. Chambers, David L. (1989) Accomodation and Satisfaction: Women and Men Lawyers and the Balance of Work and Family, 14 Law and Social Inquiry 251-287.

Chambliss, Elizabeth (2000) Miles to Go 2000: Progress of Minorities in the Legal Profession. Chicago: American Bar Association, Commission on Racial and Ethnic Diversity in the Profession.

Dau-Schmidt, Kenneth G., \& Kaushik Mukhopadhaya (1999) The Fruits of our Labors: An Empirical Study of the Distribution of Income and Job Satisfaction Across the Legal Profession, 49 Journal of
Legal Education 342-366.

Dixon, Jo \& Carroll Seron (1995) Stratification in the Legal Profession: Sex, Sector and Salary. Law and Society Review 29:381-412.

Dezalay, Yves \& Bryant G. Garth (2002) The Internationalization of Palace Wars: Lawyers, Economists, and the Contest to Transform Latin American States. Chicago: University of Chicago Press.

Dinovitzer, Ronit, Bryant G. Garth, Richard Sander, Joyce Sterling, and Gita Z. Wilder. 2004 After the JD: First Results of a National Study of Legal Careers. American Bar Foundation and NALP, http:// www.americanbarfoundation.org/afterjd.html (accessed 13 July 2006).

Dolan, Maura (1995) Miserable with the Legal Life. Los Angeles Times, June 27, 1995 at A1.

Eviatar, Daphne (2000) Out of court Evidence shows lawyers are leaving the legal profession. Unfulfilled, tired of conflict, many seek a new simplicity Christian Science Monitor Apr 17, p. 11.

Firebaugh, Glenn and Brian Harley (1995) Trends in Job Satisfaction in the United States by Race, Gender, and Type of Occupation. 5 Research in the Sociology of Work, p. 87-104.

Galanter, Marc \& Thomas Palay (1991) Tournament of Lawyers: The Transformation of the Big Law Firm. Chicago: University of Chicago Press.

Ganzeboom, Harry B.G. \& Donald J. Treiman (1996) Internationally Comparable Measures of Occupational Status for the 1988 International Standard Classification of Occupations. 25 Social Science Research 201-239.

Gellis, Ann J. (1991) Great Expectations: Women in the Legal Profession, A Commentary on State Studies, 66 Indiana Law Journal 941-976.

Glendon, Mary Ann (1994) A Nation Under Lawyers: How the Crisis in the Legal Profession is Transforming American Society. New York: Farrar, Straus \& Giroux.

Granfield, Robert (1992) Making Elite Lawyers: Visions of Law at Harvard and Beyond. New York: Routledge.

Hadfield, Gillian (2000) The Price of Law: How the Market for Lawyers Distorts the Justice System 98 Michigan Law Review 953-1006.

Hagan, John, Marie Huxter, \& Patricia Parker (1988) Class Structure and Legal Practice: Inequality and Mobility among Toronto Lawyers. Law and Society Review 22:9-55. 
Hagan, John, \& Fiona Kay (1995) Gender in Practice: A Study of Lawyers Lives. New York: Oxford University Press.

Halaby, Charles N. (2003) Where Job Values Come from: Family and Schooling Background, Cognitive Ability, and Gender, 68 American Sociological Review 251-278.

Heinz, John P. et al. (2005) Urban Lawyers: The New Social Structure of the Bar. Chicago: The University of Chicago Press.

Henderson, William D. (Forthcoming 2006) An Empirical Study of Single-Tier versus Two-Tier Partnerships in the Am Law 200. 84 North Carolina Law Review.

Hirsch, Ronald L. (1985) Are You on Target? 12 Barrister 17-20.

Hull, Kathleen E. (1999) The Paradox of the Contented Female Lawyer, 33 Law \& Society Review 687-702.

Jacobs, Jerry A., David Karen, \& Katherine McClelland (1991) The Dynamics of Young Men s Career Aspirations. Sociological Forum 6:609-39.

Johnson, Monica Kirkpatrick (2002) Social Origins, Adolescent Experiences, and Work Value Trajectories during the Transition to Adulthood. Social Forces 80:1307-1340.

----- (2001). Change in Job Values during the Transition to Adulthood. Work and Occupations 28:315-45.

Kalleberg, Arne L. (1977) Work Values and Job Rewards: A Theory of Job Satisfaction, American Sociological Review 124-143.

Kay, Fiona M. (1997) Flight from Law: A Competing Risks Model of Departures from Law Firms, 31 Law \& Society Review 301- 335.

Kay, Fiona M., \& John Hagan (2003) Building Trust: Social Capital, Distributive Justice, and Loyalty to the Firm, 28 Law \& Social Inquiry 483-519.

Kronman, Anthony T. (1993) The Lost Lawyer: Failing Ideals of the Legal Profession. Cambridge, MA.: Belknap Press of Harvard University Press.

Lempert, Richard O., David L. Chambers, \& Terry K. Adams (2000) Michigan s Minority Graduates in Practice: The River Runs through Law School, 25 Law and Social Inquiry 395-506.

Little, Roderick J. A. \& Donald B. Rubin (1987) Statistical Analysis with Missing Data. New York: Wiley.

Long, John S. (1997) Regression Models for Categorical and Limited Dependent Variables. Newbury
Park, CA: Sage Publications.

McDonough, Molly (2005) The Profession, Demanding diversity: Corporate Pressure Is Changing the Racial Mix at Some Law Firms. 91 ABA Journal 52.

McGill, Christa (2003) The role of educational debt in law student career choices. American Bar Foundation Working Paper No. \#2208. Chicago, IL: American Bar Foundation.

McClelland, Katherine E. (1990) The Social Management of Ambition. Sociological Quarterly 31:225-51.

Mertz, Elizabeth (forthcoming 2006) The Language of Law School: Learning to 'Think' Like a Lawyer. New York: Oxford University Press.

Mobley, G. M. et al. (1994) Mentoring, Job Satisfaction, Gender, and the Legal Profession, 31 Sex Roles 79-98.

Muir, Kate (1995) Counsel for the Depressed and the Stressed. Times (London), July 13, 1995, at 16.

NALP (2001) The Lateral Lawyer. Washington, DC: The NALP Foundation for Research and Education.

-----. (2004) NALP Directory of Legal Employers. Washington, DC: The NALP Foundation for Research and Education.

National Post (2001) Lawyers express dissatisfaction with stress levels and long working hours, survey shows National Post Apr 6, pC7.

Pedon, Kelly (2004) Shifting Gears; Law Practice Doesn't Always Make for a Perfect Career 19. Texas Lawyer February 23, p11.

Ranalli, Ralph (2003) Deep Dissatisfaction Leads Some Lawyers to Question, Abandon Profession. The Boston Globe August 18.

Reichman, Nancy and Joyce Sterling (2004) Sticky Floors, Broken Steps and Concrete Ceilings in Legal Careers, Texas Journal of Women and Law 14:27-76.

Rhode, Deborah L. (2000) In the Interests of Justice: Reforming the Legal Profession. New York: Oxford University Press.

Rose, Nikolas (1999). Powers of Freedom: Reframing Political Thought. Cambridge University Press.

Sandefur, Rebecca L., \& John P. Heinz (1999). The relationship between lawyer income and job satisfaction, Chicago, 1995. Presented at the 1999 Law \& Society Annual Meetings, Chicago, IL.

Schafer, Joseph L. (1997). Analysis of Incomplete Multivariate Data. New York: Chapman and Hall.

Schiltz, Patrick J. (1999) On being a Happy, Healthy 
and Ethical Member of an Unhappy, Unhealthy, and Unethical Profession, 52 Vanderbilt Law Review 871-951.

Seron, Carroll (1996) The Business of Practicing Law. Philadelphia: Temple University Press.

Sommerlad, Hilary \& Sanderson, Peter (1998) Gender Choice and Commitment: Women Solicitors in England and Wales and the Struggle for Equal Status. Aldershot: Ashgate Publishing. Stinchcombe, Arthur L. (2005) The Logic of Social Research Chicago: University of Chicago Press. Stover, Robert V. (1989) Making It and Breaking It: The Fate of Public Interest Commitment During Law School. Urbana, IL: University of Illinois Press.

Taber, Janet et al. (1988) Gender, Legal Education, and the Legal Profession: An Empirical Study of Stanford Law Students and Graduates, 40 Stanford Law Review 1209-1297.

Tazian, Vahe (2005) It's time for alternatives 27 The National Law Journal December 5, p31.

Tucker, Marilyn, Laurie A. Albright, \& Patricia L. Busk (1989) Whatever Happened to the Class of 1983? 78 The Georgetown Law Journal 153-195.

Uzzi, Brian, \& Ryon Lancaster (2004) Embeddedness and Price Formation in the Corporate Law Market, 69 American Sociological Review 319-344.

Wacquant, Loic. (2004) Pointers on Pierre Bourdieu and Democratic Politics Constellations 11:3-15.

Wallace, Jean E. (1995) Corporatist Control and Organizational Commitment among Professionals: The Case of Lawyers Working in Law Firms, 73 Social Forces 811-839.

Wilkins, David B. (2004) From Separate is Inherently Unequal to Diversity is Good for Business : The Rise of Market-Based Diversity Arguments and the Fate of the Black Corporate Bar, 117 Harvard Law Review 1548.

Wilkins, David B. (1999) Legal Ethics: Partners Without Power? Journal of the Institute for the Study of Legal Ethics 2:15-48.

Wilkins, David B., \& Mitu G. Gulati (1996) Why are there so Few Black Lawyers in Corporate Law Firms? An Institutional Analysis, 84 California Law Review 493-625. 